Portland State University

PDXScholar

\title{
Evaluation of a Pilot of the Oregon Department of Transportation's Ecodrive Program
}

\author{
Donald M. Truxillo \\ Portland State University \\ John MacArthur \\ Portland State University \\ Frankie Guros \\ Portland State University, fjguros@gmail.com \\ Layla R. Mansfield \\ Portland State University
}

Follow this and additional works at: https://pdxscholar.library.pdx.edu/psy_fac

Part of the Applied Behavior Analysis Commons, Other Psychology Commons, and the Transportation Commons

Let us know how access to this document benefits you.

\section{Citation Details}

Truxillo, D., et al., Evaluation of an Eco-Driving Program: Changing Knowledge, Attitudes, and Behavior. ORTEC-SS-727. Portland, OR: Transportation Research and Education Center (TREC), 2013.

http://dx.doi.org/10.15760/trec.131

This Report is brought to you for free and open access. It has been accepted for inclusion in Psychology Faculty Publications and Presentations by an authorized administrator of PDXScholar. Please contact us if we can make this document more accessible: pdxscholar@pdx.edu. 


\title{
S) OTREC
}

FINAL REPORT

\section{Evaluation of A Pilot of the Oregon}

\author{
Department of \\ Transportation's \\ Ecodrive Program
}

OTREC-SS-727

January 2014 



\title{
EVALUATION OF A PILOT OF THE OREGON DEPARTMENT OF TRANSPORTATION'S ECODRIVE PROGRAM
}

\section{Draft Report \\ OTREC-SS-727}

\author{
by \\ Donald M. Truxillo, Ph.D. \\ Portland State University \\ John MacArthur, M.S. \\ Frankie Guros, M.S. \\ Layla R. Mansfield \\ Portland State University \\ for \\ Oregon Transportation Research \\ and Education Consortium (OTREC) \\ P.O. Box 751 \\ Portland, OR 97207

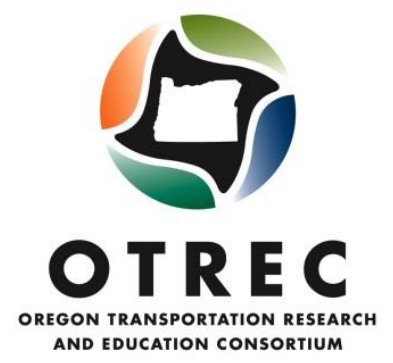

January 2014 



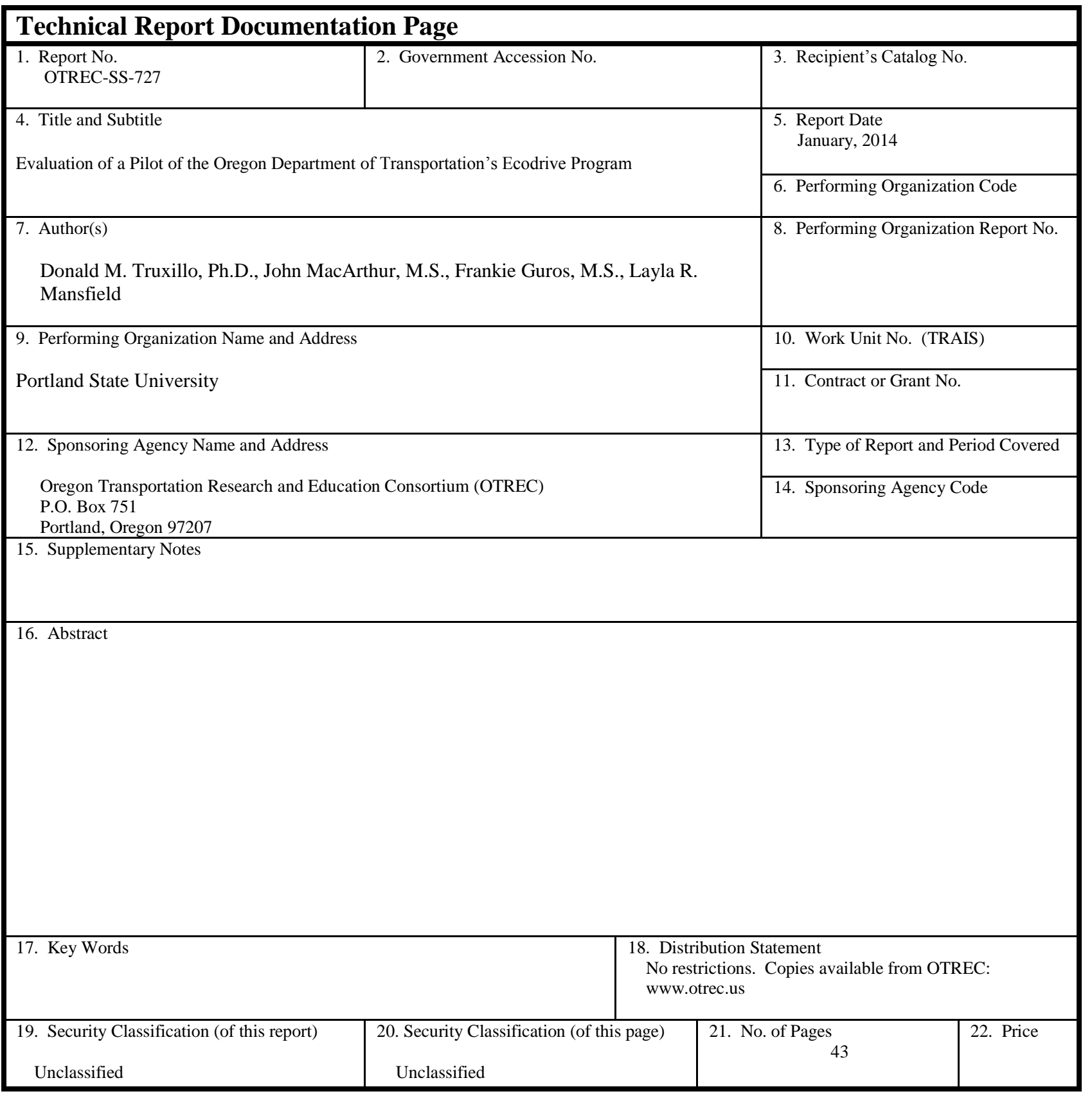





\section{Evaluation of a Pilot of the Oregon Department of Transportation's EcoDrive Program}

Donald M. Truxillo, Ph.D.

John MacArthur, M.S.

Frankie Guros, M.S.

Layla R. Mansfield

September 30, 2013

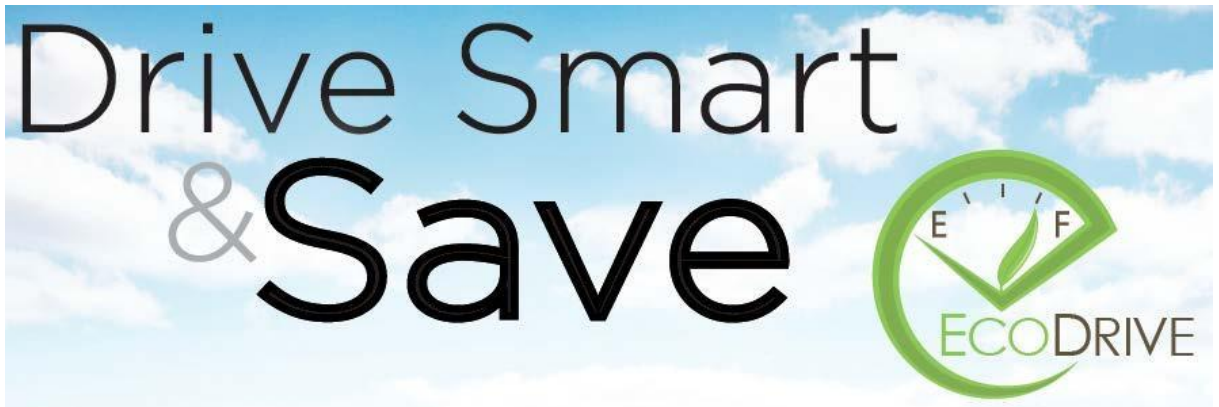





\section{Acknowledgements}

We thank the following participating organizations: Multnomah County, Washington County, the City of Hillsboro Parks Department, and the Oregon Department of Transportation (ODOT). We also thank Stephanie Millar, Senior Planner for ODOT, for soliciting participation from the organizations and for all of her support during the data collection and providing collateral material.

The contents of this report are solely the responsibility of the authors and do not necessarily represent the official views of ODOT or the participating organizations.

\section{(C) September 30, 2013}

Donald M. Truxillo, Ph.D.

Portland State University

Department of Psychology

PO Box 751

Portland, OR 97207-0751

(503) 725-3969

truxillod@pdx.edu
John MacArthur

OTREC - Oregon Transportation Research and Education Consortium

P.O. Box 751

Portland, OR 97207-0751

(503) 725-2866

macarthur@pdx.edu

\section{Reproduction}

This report may be reproduced for educational purposes and should be cited as follows:

Truxillo, D.M., MacArthur, J., Guros, F. \& Mansfield, L.R. (2013) Evaluation of a Pilot of Oregon

Department of Transportation's EcoDrive Program. Portland State University, Portland, OR. 



\section{Contents}

\begin{tabular}{ll}
\hline Introduction & 1
\end{tabular}

Characteristics of Organizations Participating in the Pilot EcoDrive Program 2

Evaluation

$\begin{array}{ll}\text { Intake Interviews } & 5\end{array}$

\begin{tabular}{|l|c|}
\hline Surveys & 5 \\
\hline Survey Results & 9 \\
\hline Exit Interview Results & 15 \\
\hline Interpretation & 17 \\
\hline Suggestions for Future Research and Application & 20 \\
\hline References & 22 \\
\hline
\end{tabular}

\begin{tabular}{|l|l}
\hline Appendix A: Overview of the EcoDrive Educational Materials & 24
\end{tabular}

Appendix B: Semi-structured Intake Interview Questions $\quad 25$

\begin{tabular}{l|l}
\hline Appendix C: Survey Questions & $\mathbf{2 7}$
\end{tabular}

Appendix D: Survey of Scales at Each Time Point 33

\begin{tabular}{|l|l|}
\hline Appendix E: Means Separated by Organization & 34
\end{tabular}

Appendix F: Evaluation of the EcoDrive Educational Materials $\quad 38$

\begin{tabular}{|l|l|}
\hline Appendix G: Exit Interview Questions for Fleet Managers/Organizational Contacts & $\mathbf{4 1}$
\end{tabular} 



\section{Introduction}

Economical, ecological, and safe driving - eco-driving - is aimed at reducing fuel consumption and greenhouse gas emissions (Martin, Chan, \& Shaheen, 2012). The adoption of energy-efficient driving styles and practices has been recognized as a means of reducing energy consumption, and estimates of energy savings attributed to eco-driving have been reported to range from $5 \%$ to as high as $20 \%$, depending on the driving context (Barkenbus, 2010; Stillwater \& Kurani, 2013; van der Voort, Dougherty \& van Maareseveen, 2001).

Eco-driving is being promoted in partnership among the Oregon Department of Transportation (ODOT) (Planning, Safety and Motor Carrier Division), the Department of Environmental Quality, the Oregon Department of Energy, and the Clean Cities Program ("EcoDriving Agency Partners") to address fuel consumption in fleet drivers of light vehicles. The EcoDrive program was created to increase fuel efficiency in organizational fleets. The intent of the EcoDrive Program is to design and introduce eco-driving educational materials specifically targeted at drivers of light vehicles. The materials highlight the "Top EcoDrive Tips" and reinforce the relevant actions and benefits of eco-driving. The purpose of this report is to provide information about the implementation of the EcoDrive Program at three sites (publicsector organizations) within the state of Oregon and provide a preliminary evaluation of the program. In particular, this report will highlight how the EcoDrive Program impacted fleet drivers in terms of attitudes, knowledge, and behavior and how the drivers responded to the eco-driving materials. Further, we discuss recommendations for future implementations of the materials, highlighting possible organizational environments that are important for the success of the EcoDrive Program.

Evaluation and methodological overview. The EcoDrive program evaluated in this report (http://www.oregon.gov/ODOT/TD/TP/pages/ecodrive.aspx) involves the introduction of various educational materials developed by Pac/West Communications and ODOT (see Appendix A for a description of the educational materials and specific examples of the materials). These materials were delivered to each of the three participating organizations for dissemination.

The steps to the evaluation were as follows:

- An intake interview with fleet managers prior to dissemination of the materials. This was to assess current organizational initiatives related to eco-driving, the nature of the fleets, current fuel use, logistics for survey administration, and other key organizational characteristics. 
- The collection of employee baseline data through a survey (Time 1) to assess employee (driver) attitudes, knowledge, and behavior prior to dissemination of the EcoDrive intervention. We also assessed the "readiness" of the individual drivers (e.g., motivation) and the organization (e.g., perceived supervisor support for eco-driving).

- Two additional employee surveys (Time 2 and Time 3), administered two weeks and six weeks after dissemination of the materials to assess change in employee attitudes, knowledge, and behavior.

- A debrief interview was conducted with the fleet managers to obtain additional insights and recommendations regarding the EcoDrive program.

\section{Characteristics of Organizations Participating in the Pilot EcoDrive Program Evaluation}

Three public sector organizations agreed to participate in the EcoDrive Program and the evaluation process: Multnomah County, Washington County, and the Parks Department for the City of Hillsboro (see Table 1 for a summary of the participants). For each of these organizations, Time 1 individual driver knowledge, attitudes, and self-report behaviors were compared to Time 2 and Time 3. Those receiving the intervention served as their own controls by comparing their post-intervention scores at two time points with their pre-intervention, baseline scores. We examined change in driver knowledge, attitudes and performance, as well as which factors (e.g., motivation) enhanced the effectiveness of the EcoDrive Program with certain individuals.

A majority of the participants worked for Multnomah County (61\%). The participants were mainly male (66\%) and Caucasian (85\%) across the three organizations. Nearly all of the participants had obtained education beyond high school. The average time the participants had worked at their respective organization was about 10 years across organizations. Participants from Washington County reported that they expected to drive for the highest number of hours per week for work (10.5), followed by Multnomah County (7) and Hillsboro Parks Department (5.93).

Table 1

EcoDrive Participants - Summary*

\begin{tabular}{|l|c|c|c|c|}
\hline & $\begin{array}{c}\text { Multnomah } \\
\text { County }\end{array}$ & $\begin{array}{c}\text { Washington } \\
\text { County }\end{array}$ & $\begin{array}{c}\text { Hillsboro } \\
\text { Parks Dept. }\end{array}$ & Total \\
\hline Total \# of Participants (All surveys) & $\mathbf{8 5}$ & $\mathbf{2 0}$ & $\mathbf{3 5}$ & 140 \\
\hline Age (years) & 47.5 & 42.8 & 38.8 & 44.5 \\
\hline
\end{tabular}




\begin{tabular}{|l|c|c|c|c|}
\hline$\%$ Male & $61 \%$ & $83 \%$ & $86 \%$ & $66 \%$ \\
\hline \% White (non-Hispanic) & $83 \%$ & $86 \%$ & $88 \%$ & $86 \%$ \\
\hline \% Education beyond high school & $97 \%$ & $100 \%$ & $71 \%$ & $94 \%$ \\
\hline Tenure (years with organization) & 10.59 & 9.17 & 8.57 & 10.11 \\
\hline $\begin{array}{l}\text { About how many hours do you } \\
\text { expect to drive each week for } \\
\text { work? }\end{array}$ & 7.00 & 10.5 & 5.93 & 7.29 \\
\hline
\end{tabular}

* Total \# of participants reflects all time points combined. Demographics collected at Time 1.

\section{Table 2}

Fleet Composition of Eco-driving Organizations

\begin{tabular}{lccc}
\hline & Multnomah County & Washington County & Hillsboro Parks Dept. \\
\hline $\begin{array}{l}\text { \# of light-duty } \\
\text { vehicles }\end{array}$ & $334^{*}$ & 19 & 57 \\
\# of hybrids/electric & $2 / 4$ & $6 / 0$ & $1 / 1$ \\
\hline
\end{tabular}

*In Multnomah County, the EcoDrive program was mostly focused on 70 motor pool cars and three locations, including an additional 200 vehicles.

Through our interviews with the fleet managers, we found these organizations had some similar experiences with eco-driving strategies prior to the introduction of the EcoDrive Program (see Table 3). Each organization had previously been involved in fuel-saving measures to some extent, but these measures were never referred to as "eco-driving." Furthermore, none of these fuel-saving measures were scientifically evaluated to determine their effectiveness or the level of implementation. For example, Multnomah County had instituted a "no-idling" program a few years ago in an attempt to reduce the amount of time drivers spent running the engine while their vehicle was parked, but this program was never evaluated. In addition, each fleet manager mentioned that although vehicles are on a preventive maintenance schedule, including oil changes and engine and tire checks, they saw the ODOT program as a way to enhance fleet driver awareness about vehicle maintenance. In sum, although these organizations had encouraged some of the eco-driving tips prior to the EcoDrive Program, they were a good fit for the ODOT program due to motivation to participate and a previous lack of a consistent messaging about eco-driving.

Table 3

Examples of Organizational Fuel-Saving Activities Prior to Intervention

\begin{tabular}{|l|c|c|c|}
\hline \multicolumn{1}{|c}{} & \multicolumn{1}{c}{$\begin{array}{l}\text { Multnomah } \\
\text { County }\end{array}$} & \multicolumn{1}{l}{$\begin{array}{l}\text { Washington } \\
\text { County }\end{array}$} & \multicolumn{1}{l}{$\begin{array}{l}\text { Hillsboro Parks } \\
\text { Dept. }\end{array}$} \\
\hline Drive at a slow and steady speed. & & & \\
\hline Accelerate/break gradually & & $\mathrm{X}$ & \\
\hline
\end{tabular}




\begin{tabular}{|l|c|c|c|}
\hline Spend less time idling your engine & $\mathrm{X}$ & $\mathrm{X}$ & $\mathrm{X}$ \\
\hline Keep tires inflated & & $\mathrm{X}$ & $\mathrm{X}$ \\
\hline Maintain your vehicle properly & & & $\mathrm{X}$ \\
\hline $\begin{array}{l}\text { Leave unnecessary weight out of your } \\
\text { vehicle }\end{array}$ & $\mathrm{X}$ & $\mathrm{X}$ & \\
\hline $\begin{array}{l}\text { Use the heating and cooling systems } \\
\text { sparingly }\end{array}$ & $\mathrm{X}$ & & \\
\hline Close windows at high speeds & $\mathrm{X}$ & $\mathrm{X}$ & $\mathrm{X}$ \\
\hline Choose the correct oil for your vehicle & & $\mathrm{X}$ & $\mathrm{X}$ \\
\hline Plan ahead to consolidate trips & & $\mathrm{X}$ & $\mathrm{X}$ \\
\hline Avoid quick starts and stops & & & \\
\hline
\end{tabular}

Note: $X$ = tip emphasized by organization prior to EcoDrive Program; blank = little to no previous formal discussion of eco-driving tips within the organizations

In all of the organizations, we were informed that each organization was looking for ways to reduce fuel consumption and lower operating costs. In fact, one participant noted that this type of study and program were "exactly the type of project we are looking to do to promote sustainability." Each participating organization voiced their motivation to conduct this research, and was eager to see whether the educational materials would promote eco-driving in their organization. The fleet managers each agreed that timing was right for the introduction of such a program, given the increased focus on sustainability at the national and global levels and the focus on state budgets in Oregon. Additionally, we assessed attitudes towards conserving energy to determine the participants" "readiness" to engage in eco-driving behaviors. The mean score was 5.83 (on a scale of 1-7), indicating that the participants had favorable attitudes towards conserving energy (see Table 11). As another indicator of participants' readiness, we assessed motivation to engage in eco-driving. The mean score was 5.88 (on a scale of 1-7), again indicating that, overall, the participants were motivated to practice good eco-driving behaviors.

Each organization had its unique characteristics as well. We found explanations in the interviews for some reported differences in these organizations. For instance, participants from the Hillsboro Parks Department reported they drove about six hours per week for work. The fleet manager there noted that they had reorganized their work in the past few years so their employees would spend less time driving. For instance, they assigned one employee - rather than several employees - to an entire park. This allowed the employee to spend their entire day at one location, rather than traveling with two or three other employees to 2-4 parks daily. Other differences included fuel tracking and stages of commitment to fuel reduction. For example, both Washington County and the City of Hillsboro track fuel use and have done so for quite some time, whereas Multnomah County is just beginning to record fuel use. 


\section{Organizational Fuel Use Data}

The project's intent was to try to examine how the EcoDrive strategies are effective in changing an individual's driving behavior and reducing fuel use. Because of the level of how the organizations in the project track both vehicle usage and who uses which vehicle, fuel usage data could not be obtained in sufficient detail, so it could be attributed to the interventions.

NOTE to Stephanie: Since the surveys and interviewed just ended, we are still trying to get more specific data from some of the agencies. Our best hope is Washington County. We are still waiting for their fleet manager to compile vehicle and fuel data.

\section{Intake Interviews}

We began the program's evaluation with interviews with four fleet managers and/or organizational contacts within the three participating organizations. There were five interviews total, as one fleet manager was interviewed twice. Each interview was approximately 45 minutes long and was conducted to obtain information on the fleet composition, fuel usage and organizational structure, as well as the current policies and procedures around fuel efficiency (e.g., idle-free programs). The semi-structured interviews allowed the Portland State University (PSU) researchers to develop organization-specific surveys (see the Surveys section for a description) and were conducted to assess the organizational fit with the EcoDrive Program. The semi-structured interviews also allowed the organizational representative to ask questions about the evaluation process, and express any concerns with the evaluation portion of the EcoDrive Program. A complete list of the interview questions can be found in Appendix B.

\section{Surveys}

The effectiveness of the EcoDrive Program was evaluated using a series of surveys in a pre-test/post-test time series, with a no-controls group design (a quasi-experimental design.) This design was used to capture participants' (drivers') eco-driving attitudes, knowledge, and behaviors prior to the intervention; to see if there were any effects on these outcomes immediately after the intervention; and to observe whether these effects lasted one month later. The pre-test (Time 1, baseline) was conducted before implementation of the program (see Appendix $\mathrm{C}$ for the complete survey across all three time points). A post-test (Time 2) occurred two weeks after the implementation of these materials; a second post-test (Time 3) occurred approximately four weeks after Time 2 (see Appendix D for a table of measures used in the surveys). To increase participation, each survey was open for two weeks, and a series of reminders was sent out by PSU researchers as well as by each of the organizations. Further, each survey included an incentive in the form of a lottery for three $\$ 25$ gift cards (total nine gift 
cards) for two of the three organizations (as one organization opted out of including the incentive).

\section{Survey Measures}

The measures within the survey were selected based on past research on eco-driving and behavior change. Measures from related types of intervention research (training, safety programs) were also used to assess employee and organizational readiness for the intervention. Our intention for the surveys was to use evaluation criteria that would directly assess driver attitudes, knowledge, typical driving behaviors, and eco-driving behaviors. We also aimed to assess several factors - factors within the individual and in the work context - that may influence whether or not the EcoDrive Program is successful. Specifically, we included measures of typical organizational variables that may influence the effectiveness of changes in behavior, such as a supportive organizational climate and supervisor support, as well as individual differences that affect behavior change, such as driver attitudes and motivation regarding energy consumption.

Specific measures included eight major categories. Three outcome measures (Ecodriving Knowledge, Eco-driving Practices, and Eco-driving Behaviors) assess the driving knowledge and driving habits in the organizations; four (Energy-reducing Attitudes, EnergyReducing Motivation, Organizational Support for Eco-driving, Supervisor Support for Ecodriving) assess individual and organization "readiness" factors that past research has shown to influence the success of similar organizational interventions; and one (Utility Evaluation) evaluates the EcoDrive Program. Below, we have listed definitions and examples for the constructs and scales.

Outcome measures. The following three categories of outcomes were assessed across all three time points.

Eco-driving knowledge. Eco-driving knowledge is self-assessed knowledge that one has about eco-driving practices and behaviors. Two items assessed change in knowledge across the three time points. Higher scores on these items indicate higher knowledge. A sample item is, "I am aware of what 'eco-driving' practices are and could briefly explain them to another person."

Eco-driving practices. Eco-driving practices are those general practices found to be important in previous eco-driving studies and was assessed with five items. These include overall vehicle maintenance and driving behaviors (Martin, Chan \& Shaheen, 2012). A sample item is, "In terms of fuel usage, how efficiently do you think you drive your work vehicle now?"

Eco-driving behaviors. Eco-driving behaviors are those behaviors based on the top ecodriving tips, as outlined in the educational materials developed by Pac/West Communications 
and ODOT. These were assessed with 11 items. A sample item is, "How likely are you to drive at a slow and steady speed?" This scale was included in the survey to ascertain behaviors both pre- and post-implementation in regards to the top-10 EcoDrive tips. Cronbach's alpha ranged from .74 to .89 .

Individual and organizational readiness measures. The following four measures were used to assess driver and organizational readiness for the EcoDrive Program. Although they have not been assessed in the extant literature on eco-driving, these variables have been shown to consistently predict the success of organizational interventions. For example, these variables, which reflect both the individual (motivation) and the context (organizational and supervisor support) have been shown to be important to the successful implementation of similar organizational programs (e.g., training, safety). Cronbach's alpha for organizational support ranged from .81 to .94. Cronbach's alpha for supervisor support ranged from .83 to .97.

Energy-reducing attitudes. Energy-reducing attitudes is the overall concern one may have about saving fuel or reducing energy consumption and was assessed by five items. A sample item is, "I am motivated to save energy." This scale was included in the survey because research has shown that energy-reducing attitudes are related to eco-driving attitudes (Harvey et al., 2013). Cronbach's alpha was .80.

Motivation. There are three subscales of this measure (eight items total) to reflect the three primary components of motivation described by expectancy theory when applied to an energy-reducing context (Van Eerde \& Thierry, 1996). First, valence is conceptualized as the value placed on energy/fuel efficiency at work. A sample item of valence is, "I think it's important to learn how to save gasoline." Second, instrumentality is the belief that energyreducing behaviors will lead to fuel-efficient/cost-saving outcomes. A sample item of instrumentality is, "There are things that I can do that will influence fuel efficiency." Finally, expectancy is the belief that expending effort will lead to fuel-efficient behavior. A sample item of expectancy is, "I can actually improve my car's fuel efficiency if I try." This scale was included in the survey because past research has shown that higher motivation increases the likelihood that we will see changes in attitudes and behaviors toward organizational training programs (Zaniboni, Fraccaroli, Truxillo, Bertolino \& Bauer, 2011). Cronbach's alpha was .91.

Organizational support for eco-driving. Organizational support is the group's perception of the organizational climate toward fuel efficiency and energy reduction. These include perceptions about the organizational policies, practices, and procedures surrounding ecodriving and was assessed with three items. A sample item is, "My organization places a strong emphasis on efficient driving behaviors." This scale was included in the survey because past research indicates that it predicts the success of similar organizational interventions (e.g., safety programs and training) (e.g., Neal \& Griffin, 2006). 
Supervisor support for eco-driving. Supervisor support is similar to organizational support except that it is the perception that the supervisor supports fuel efficiency and energy reduction. These include perceptions about the supervisors' support of the policies, practices, and procedures surrounding eco-driving. Supervisor support was assessed through three items. A sample item is, "My supervisor places a strong emphasis on efficient driving behaviors." Higher scores on this measure indicate a more positive perception of supervisor support toward eco-driving. This scale was included in the survey because past research indicates that a supportive supervisor is positively related to the success of organizational programs such as safety programs (e.g., Neal \& Griffin, 2006).

Utility evaluation. Perceived utility is the reaction that participants have toward the EcoDrive program in terms of its value to participants. Research indicates that utility reactions are related to learning and behavior change (Alliger, Tannenbaum, Bennett \& Traver, 1997). That is, the more a participant believes that the EcoDrive Program is useful and effective, the more likely they will be to learn about eco-driving and use the knowledge back on the job. Utility evaluation was assessed through four items. A sample item is, "How effective do you think the eco-driving program is overall?" Utility evaluation was assessed after the intervention (Time 2 and Time 3).

\section{Survey Responses}

We were able to use the interviews to estimate the number of expected participants from each organization. Our contacts at Washington County recruited several of their smaller departments to participate in the study, and expected that about 10-20 employees would participate. Hillsboro Parks Department targeted all of their 50 employees for participation. It was more difficult to predict our participant population in Multnomah County, as we sent the survey via a county-wide newsletter and used an exclusion criterion to solicit participants. Each organization distributed our surveys to a variety of participants, and our final sample size varied based on the organization and which survey time we assessed. Across all organizations, there were 105 participants at Time 1, 73 participants at Time 2, and 67 participants at Time 3 (see Table 4).

Since we were interested in assessing changes over time, we matched the surveys of participants who filled out a survey at more than one time point. We were able to match survey responses for 51 participants from Time 1 to Time 2 and 38 participants from Time 1 to Time 3 . 


\section{Table 4}

Participant Number by Organization and Survey Time

\begin{tabular}{|l|c|c|c|c|}
\hline & $\begin{array}{c}\text { Multnomah } \\
\text { County }\end{array}$ & $\begin{array}{c}\text { Washington } \\
\text { County }\end{array}$ & $\begin{array}{c}\text { Hillsboro Parks } \\
\text { Dept. }\end{array}$ & Total \\
\hline Time 1 & 77 & 15 & 33 & 105 \\
\hline Time 2 & 50 & 13 & 10 & 73 \\
\hline Time 3 & 44 & 14 & 9 & 67 \\
\hline $\begin{array}{l}\text { Total (unique } \\
\text { participants) }\end{array}$ & 85 & 20 & 35 & $140^{*}$ \\
\hline
\end{tabular}

* Of the 140 participants, we were able to match surveys for 51 of the participants from Time 1 to Time 2 and 38 of the participants for Time 1 to Time 3.

\section{Survey Results}

The following section highlights survey findings. These will be reported by organization and survey time ( $T 1, T 2$, or $T 3)$. The majority of the results pertain to participants who could be matched from T1 (baseline) to T2 and from T1 to T3 and will focus on statistically significant changes. Note that the data for all three organizations were combined for these analyses because the numbers of matched participants for Hillsboro and Washington County were small. Data for all (unmatched) participants is reported in Appendix E by organization.

\section{Eco-driving Knowledge}

Eco-driving knowledge refers to the understanding one may have about eco-driving practices. We assessed eco-driving knowledge with two items (see Table 5). The first, "I am aware of what 'eco-driving' practices are and could briefly explain them to another person" was significantly different among those matched participants pre- and post-eco-drive program. The second item that assessed eco-driving knowledge asked participants to list examples of the ecodriving practices as outlined on the eco-driving educational materials. This indicator of knowledge also increased at Time 2 and Time 3 compared to Time 1 . These findings indicate that the EcoDrive Program may have increased knowledge about eco-driving from baseline to two weeks after the implementation of the materials and this increase in knowledge was maintained through Time 3. 
Table 5

\section{Eco-driving Knowledge}

\begin{tabular}{|l|l|l|l|}
\hline \multicolumn{1}{|c|}{ Item } & T1 & T2 & T3 \\
\hline 1. EcoDrive knowledge (explain to another person) & 4.22 & $5.65^{* *}$ & $5.61^{* *}$ \\
\hline 2. EcoDrive knowledge (named 1-2 eco-drive behaviors) & $67 \%$ & $91 \% * *$ & $76 \% * *$ \\
\hline
\end{tabular}

$* *$ Indicates a significant change of $p<.001$ from Time 1 value. Time 1 to Time 2 comparison: $\mathrm{N}=46$. Time 1 to Time 3 comparison: $\mathrm{N}=31$. Note: Responses on 1 (Strongly Disagree) to 7 (Strongly Agree) scale for the first question. A response of 4 would be neutral. The second question was on a 1 (Yes) to 2(No) scale.

Summary. Overall, our findings indicate that eco-driving knowledge increased in the participants across the three organizations.

\section{Eco-driving Practices}

Eco-driving practices are those general practices found to be important in previous ecodriving studies.

Overall, we found that the participants felt that their fleet vehicles were maintained well (see Table 6) and this did not change significantly throughout the EcoDrive Program. Participants also reported that they drove their work vehicle efficiently, though this also did not change from the reported mean at Time 1.

There was an increase at Time 2 in how often participants adjusted their driving behavior to improve their fuel economy, but this change was not maintained at Time 3 . Additionally, at Time 3 participants reported a significant increase in how often they conducted a pre-trip inspection before driving their work vehicle. Finally, the average time to warm up one's vehicle did not change over time.

\section{Table 6}

\section{Eco-driving Practices - All Organizations}

\begin{tabular}{|l|c|c|c|}
\hline \multicolumn{1}{|c|}{ Item } & T1 & T2 & T3 \\
\hline $\begin{array}{l}\text { 1. Overall, how well do you think that your fleet } \\
\text { car is maintained? }\end{array}$ & 5.27 & 5.51 & 5.33 \\
\hline $\begin{array}{l}\text { 2. In terms of fuel usage, how efficiently do you } \\
\text { think you drive your work vehicle now? }\end{array}$ & 5.42 & 5.57 & 5.33 \\
\hline $\begin{array}{l}\text { 3. When driving your primary work vehicle, } \\
\text { how often do you adjust your driving behavior } \\
\text { in ways to improve your fuel economy? }\end{array}$ & 4.57 & $5.15^{*}$ & 4.97 \\
\hline
\end{tabular}




\begin{tabular}{|l|c|c|c|}
\hline $\begin{array}{l}\text { 4. When driving your primary work vehicle how } \\
\text { often do you conduct a pre-trip inspection (e.g., } \\
\text { check the oil and tire pressure)? }\end{array}$ & 1.81 & 2.11 & $3.16^{*}$ \\
\hline $\begin{array}{l}\text { 5. On cold mornings, how long do you typically } \\
\text { warm up the car before starting your trip? (in } \\
\text { seconds) }\end{array}$ & 30 & 30 & 30 \\
\hline
\end{tabular}

*Indicates a significant change of $p<.01$ from Time 1 value. Time 1 to Time 2 comparison:

$\mathrm{N}=44$. Time 1 to Time 3 comparison: $\mathrm{N}=33$. Note: Responses on 1 (Not well/never/inefficiently) to 7 (Very well/always/efficiently) scale. A response of 4 would be neutral.

Summary. Overall, our findings indicate that there was an increase how drivers adjusted their driving behavior in ways to improve their fuel economy at Time 2, and it increased how often they conducted a pre-trip inspection at Time 3.

\section{Eco-driving Behaviors}

Eco-driving behaviors were the 11 behaviors presented in the EcoDrive Program materials.

We analyzed changes in the 11 individual behaviors, and in eco-driving behaviors as an average score (see Table 7). Participants reported an increase in driving at a slow and steady speed at Time 2, as well as an increase in accelerating and braking gradually at Time 2 . It is possible that these were the behaviors that the participants felt they had the greatest control over, or were perceived as the easiest behaviors to engage in. Overall, though, eco-driving behaviors did not change significantly at Time 2 and Time 3 compared to Time 1.

Table 7

Eco-driving Behaviors - All Organizations

\begin{tabular}{|l|c|c|c|}
\hline \multicolumn{1}{|c|}{ Item } & T1 & T2 & T3 \\
\hline 1. Drive at a slow and steady speed. & 5.35 & $5.76^{*}$ & 5.62 \\
\hline 2. Accelerate/brake gradually & 5.54 & $5.82^{*}$ & 5.43 \\
\hline 3. Spend less time idling your engine & 5.38 & 5.53 & 5.68 \\
\hline 4. Keep tires inflated & 4.94 & 4.48 & 4.46 \\
\hline 5. Maintain your vehicle properly & 5.03 & 4.88 & 4.89 \\
\hline 6. Leave unnecessary weight out of your vehicle & 5.44 & 5.44 & 5.19 \\
\hline 7. Use the heating and cooling systems sparingly & 5.00 & 4.70 & 4.95 \\
\hline 8. Close windows at high speeds & 5.65 & 5.82 & 5.59 \\
\hline 9. Choose the correct oil for your vehicle & 5.26 & 4.89 & 4.64 \\
\hline 10. Plan ahead to consolidate trips & 5.78 & 5.84 & 5.92 \\
\hline 11. Avoid quick starts and stops & 5.59 & 5.73 & 5.62 \\
\hline Overall Eco-driving Behavior Score & $\mathbf{5 . 2 0}$ & $\mathbf{5 . 3 2}$ & $\mathbf{5 . 2 6}$ \\
\hline
\end{tabular}

Time 1 to Time 2 comparison: $\mathrm{N}=49$. Time 1 to Time 3 comparison: $\mathrm{N}=37$. Note: 
Responses on 1 (Very unlikely) to 7 (Very likely) scale. A response of 4 indicates undecided.

Summary. Overall, our findings indicate that two of the eco-driving behaviors increased in the participants across the three organizations. These behaviors appear to be actual driving behaviors over which drivers may believe that they have some control. We also note that there may be a "ceiling effect" at play here, in that most of the participants were performing these behaviors at a high rate even at baseline (i.e., they were well above the midpoint of a 1-7 scale.)

\section{Organizational Support for Eco-driving}

Organizational support is the perception of the organizational climate toward fuel efficiency and energy reduction. These include perceptions about the organizational policies, practices, and procedures surrounding eco-driving.

We observed a change in organizational support that was marginally significant at Time 2 (see Table 8). The increase in organizational climate perceptions is important because research indicates that a supportive climate facilitates learning and behavior change during an intervention (Neal \& Griffin, 2006; Zohar, 1980). Therefore, this increase may predict future changes in eco-driving behavior. Thus, although we did not see an immediate change in ecodriving behaviors it is possible that a supportive climate maintained over time will assist in future behavior change.

\section{Table 8}

Organization Support for Eco-driving - All Organizations

\begin{tabular}{|l|c|c|c|}
\hline & T1 & T2 & T3 \\
\hline Organizational Support for Eco-driving & 4.31 & $4.66^{\dagger}$ & 4.49 \\
\hline
\end{tabular}

+ indicates a marginally significant change of $p<.10$ from Time 1 value.

Time 1 to Time 2 comparison: $\mathrm{N}=48$. Time 1 to Time 3 comparison: $\mathrm{N}=36$.

Note: Responses on 1 (Strongly disagree) to 7 (Strongly agree) scale. A response of 4 indicates neutral.

\section{Summary. Overall, our findings indicate that organizational support for eco-driving} increased from Time 1 to Time 2, but this change was not evident at Time 3. Also, the values were near the mid-point of the 1-7 scale, indicating that organizational support for eco-driving could have been higher and may have affected the results of the intervention. 


\section{Supervisor Support for Eco-driving}

Supervisor support is similar to organizational support, except this is the perception that the supervisor supports fuel efficiency and energy reduction. This includes perceptions about how the supervisor prioritizes eco-driving and whether they emphasize eco-driving practices.

We observed a change in supervisor support that was marginally significant at Time 2 (see Table 9). This increase in supervisor support may also be important for future behavior changes. Although organizations often have formal policies that support employees, supervisors often act as the "linking pin" between these policies and the employees by providing the necessary supports in a more direct manner to employees (Hammer et al., 2009).

\section{Table 9}

\section{Supervisor Support for Eco-driving - All Organizations}

\begin{tabular}{|l|c|c|c|}
\hline & T1 & T2 & T3 \\
\hline Supervisor Support for Eco-driving & 3.83 & $4.09^{\dagger}$ & 4.00 \\
\hline
\end{tabular}

Time 1 to Time 2 comparison: $\mathrm{N}=48$. Time 1 to Time 3 comparison: $\mathrm{N}=36$.

Note: Responses on 1 (Strongly disagree) to 7 (Strongly agree) scale. A response of 4 indicates neutral.

Summary. Overall, our findings indicate that supervisor support for eco-driving increased from Time 1 to Time 2, but this change was not evident at Time 3. Also, the values were near the mid-point of the 1-7 scale, indicating that supervisor support for eco-driving could have been higher and may have affected the results of the intervention.

\section{Utility Reactions}

To assess the perceived effectiveness of the EcoDrive Program from the viewpoint of participants, we examined perceived utility with the overall program. Perceived utility is the reaction the participants had toward the EcoDrive Program. The more a participant believes that the EcoDrive program is useful and effective, the more likely they will be to learn about eco-driving and use the knowledge on the job. The utility evaluation mean was 4.36 at Time 2 and 4.39 at Time 3, indicating participants slightly felt that the EcoDrive Program was useful (see Table 15).

\section{Evaluation of the Eco-driving Educational Materials}

Beyond examining the utility of the EcoDrive Program in general, we also attempted to ascertain the effectiveness of each of the educational materials. Overall, we found that few (20\%; see Appendix F for complete results) participants reported that they saw the EcoDrive materials in their workplace. Although our study design does not allow us to conjecture as to 
why so few participants reported seeing the study materials, we may conclude that either 1) the materials were presented too passively (i.e., just placed on tables with no discussion) or 2) the participants saw the materials, integrated the information into their knowledge and then became so habituated to the eco-driving materials that they did not recall them on the survey.

In our exit interviews we asked how the materials were distributed and found that the while the organizations placed the materials in high traffic areas, only a couple of the supervisors made it a point to discuss the EcoDrive Program and materials. Thus, while the placement of the materials is important, the materials may not have been noticed by the majority of the fleet drivers in those departments where there was no other promotion of the materials by supervisors. Therefore, we note that the survey, which asked about elements of eco-driving, may in itself have acted as a way of disseminating eco-driving information to participants. This suggests that future eco-driving interventions should not only place the materials, but also integrate supervisor promotion of the materials and support.

Further, research supports the notion of habituation, suggesting that while the novelty of a sign or label may capture one's attention at the onset of the introduction of an intervention this novelty is quickly lost and the message of the sign or label is forgotten (Wogalter \& Laughery, 1996). Therefore, although the driver may have noticed the eco-driving materials with no organizational intervention or prodding, we cannot be sure they actually read the materials. Further, if they did read the materials - again without reminders coming from the organization or supervisors - the fleet drivers may have forgotten the intent of the EcoDrive message.

Although only $20 \%$ of the participants reported viewing the materials, the overall perceived utility of the educational materials was relatively high. The educational material that participants perceived as the most effective was the ODOT website followed by the window cling. The videos were the least likely to be viewed and were perceived as the least effective in changing a fleet driver's behavior. Future interventions should make the videos a mandatory part of training for fleet drivers. Further, videos that are tailored for different drivers (i.e., videos that depict fleet drivers and issues) will be more effective and will provide a powerful message to drivers. 


\section{Exit Interview Results}

We conducted exit interviews with each of the organizations to ascertain how the materials were distributed and the extent to which the materials were promoted within each of the organizations (see Appendix $\mathrm{G}$ for complete interview questions). Further, these interviews allowed the organizations to give us informal feedback on how they felt the EcoDrive Program was received by their employees and provide critiques and recommendations for future Ecodriving interventions. In the interest of anonymity, the following report will group all organizations together.

\section{Distribution of Materials}

Each of the organizations utilized each of the educational materials provided by ODOT. Posters were placed in break rooms and high-traffic areas where the drivers congregate or check out their vehicles. Tip cards were placed at each computer terminal, on break tables, and in vehicles. Window clings were placed in the majority of vehicles, and two organizations reported that window clings were placed in all of their vehicles. In some of the organizations, employees were given time to view the videos while at work. In other organizations, emails were sent out to employees with links to the ODOT website and the videos. They were not, however, given specific time at work to watch the videos or review the materials.

Our contacts in the organizations allowed supervisors to place all of the materials in their workplaces. In this respect, there were reported differences among organizations where the supervisor was supportive of the program and the distribution of the materials. For example, in one organization materials were placed in prominent areas where employees would be most likely to see them during breaks in the work day, and the tip cards were personally handed to fleet drivers. In contrast, in another organization the materials were put in place much later and not in time for the second survey. In summary, each organization placed the materials in high-traffic areas, but the promotion of the material ranged from a very passive approach (i.e., just hanging up posters) to a more aggressive approach, with the integration of the educational materials into employee meetings and discussions. However, no organization formalized the process to the point that they tracked which employees watched the videos, or ensured that $100 \%$ of the employees who drove fleet vehicles watched the videos. Additionally, since some of the organizations distributed their materials to several departments in different geographical locations, our contacts were uncertain as to how exactly the materials were distributed in certain locations. 


\section{Reaction to the EcoDrive Materials}

Overall, our contacts were receptive to the educational materials and provided positive feedback about them. Further, each reported that the materials were very effective in increasing knowledge about eco-driving. Each of the organizations discussed integrating the materials in future trainings and initiatives. The ease of access to the materials on the ODOT website was highly valued, as was the diversity of the materials. That is, having the eco-driving information in multiple formats allowed the organization to tailor their placement. Supervisors received positive informal feedback from employees about the materials. There was slight negative feedback about eco-driving in general from some of the fleet drivers, but this tended to decrease over time as the fleet drivers became aware that they were already engaging in eco-driving practices and with the increase in supervisor and peer support of eco-driving. In summary, the materials were received positively by both the fleet drivers and the organizational contacts. The organizations will continue to use and support the EcoDrive Program. In fact, several of the contacts in the organizations had almost run out of the materials and expressed a strong interest in receiving additional materials. In the same vein, they also thought that "booster" trainings occurring sometime after the initial distribution of materials would be a strong way of reiterating eco-driving behaviors and practices.

\section{Suggestions}

In our exit interviews, we also received suggestions for future interventions and the ecodriving materials. First, there was concern about the timing of the intervention. The intervention occurred during the summer months when many of the fleet drivers take vacation; therefore, there were many drivers who missed some or all of the intervention period. Further, in one organization there is an influx of seasonal employees who may not have understood the context of the intervention. Second, the organizations felt rushed in their rollout and would have liked to spend more time gaining supervisor support and integrating the EcoDrive Program into their larger sustainability initiatives. Finally, there were a couple of suggestions about the materials. In particular, the organizations would have liked to see the materials in other languages and in different formats. For example, in one organization the tip card did not physically fit into their driver packets. If the tip card came in different formats, the organization could download the tip card from the ODOT website and place them in each of their driver packets. In summary, the materials were perceived as effective and will continue to be used by the organizations. 


\section{Interpretation}

\section{Eco-driving Behaviors: Strengths}

Overall, the drivers in these organizations reported being aware of and practicing some eco-driving behaviors. The mean scores for many of the behaviors were greater than 4 (neither agree nor disagree), indicating the participants reported engaging in certain eco-driving behaviors even before the program started. Drivers overall reported that they thought they currently drove their work vehicle efficiently in terms of fuel usage at Time 2 (mean = 5.57) and that their vehicle was well-maintained (mean $=5.51$ ). Other highly reported means for specific eco-driving behaviors across the organizations were closing windows at high speeds (5.82), planning ahead to consolidate trips (5.84), and accelerating/breaking gradually (5.82).

\section{Changes in Outcomes}

Overall, we observed some changes in the key outcome variables in the study, although some results were quite mixed, as we have displayed in Table 10 below. Our results indicate that eco-driving knowledge increased during our evaluation of the EcoDrive Program. This may suggest that participants who were exposed to the eco-driving materials learned ecodriving tips from the posters, tip cards, and other materials. However, we did not observe significant increases in most eco-driving behaviors. It may be possible that during the short timeline of our study we were not able to observe changes in behavior, which often take longer to occur than changes in knowledge.

Some individual practices and behaviors did increase over the course of the study. Participants' reports in how they adjusted their driving to improve fuel economy increased at Time 2. There was also an increase in the frequency of pre-trip inspections of the participant's work vehicles at Time 3 . This type of practice is promoted indirectly by the eco-driving materials, as several of the tips can be implemented in a pre-trip inspection (keep tires inflated, maintain your vehicle, keep unnecessary weight out of the vehicle). Two eco-driving behaviors increased at Time 2 as well: Accelerating and braking gradually, and driving at a slow and steady speed. We think these may be behaviors that employees feel they have more control over and thus are more easily changed, compared to choosing the right oil for their vehicle, for instance.

Note that a large percentage of the participants indicated that they had not viewed the materials. This is likely a factor that explains why many of the eco-driving behaviors did not change during the course of the study. It may be that the changes we observed could be attributed to influences other than the materials themselves. For instance, it is possible that by simply taking the survey questions and reading about eco-driving behaviors in the survey, the participants changed their responses at Time 2 and Time 3. 
Both organizational and supervisor support for eco-driving approached statistically significant changes from Time 1 to Time 2, although this result disappeared at Time 3 . Two possibilities are most likely. Due to participant attrition at Time 3, we may have lacked an adequate sample size to detect such significant changes. It is also possible that the initial support for eco-driving was reduced as the novelty of the program wore off. In other words, whatever effects the program may have had on support were not sustained through Time 3.

Table 10

Changes Over Time - Summary of Results of Statistical Tests*

\begin{tabular}{|l|c|c|}
\hline \multicolumn{1}{|c|}{ Outcome } & Change: Time 1 - Time 2 & Change: Time 1 - Time 3 \\
\hline Eco-Driving Knowledge & Yes & Yes \\
\hline Eco-Driving Behaviors (11 total) & $\mathbf{2 / 1 1}$ & $\mathbf{0 / 1 1}$ \\
\hline
\end{tabular}

* Analyses based on 38 participants with 'matched' surveys.

\section{Future Opportunities}

There were a few areas which were not improved by the program and should receive attention in future programs.

1. Using heating and cooling and keeping tires inflated: Though some of the behaviors discussed in the previous section were reportedly done with great frequency, others were not. These include using the heating and cooling systems sparingly (4.70); keeping tires inflated (4.48); maintaining your vehicle properly (4.88); and choosing the right oil for your vehicle (4.89) at time 2 (see Table 12). These mean values are close to the "neither agree nor disagree" response option, indicating that these behaviors may or may not occur on a regular basis. Again, these may be behaviors in which the participants did not feel they had control over or were behaviors that had obstacles preventing any change.

2. Low levels of perceived supervisor and organizational support for eco-driving: Our initial survey results indicate that both measures of support for eco-driving were fairly low (4.66 for organizational support; 4.09 for supervisor support; see Table 14). Therefore, future implementation of eco-driving should focus on how to increase this key variable of support. The eco-driving materials themselves may not directly promote organizational support or supervisor support for eco-driving. However, the introduction of the program itself and subsequent support by supervisors and organizations may enhance the program's success (see below).

\section{Key Factors to Program Success: Individual and Organizational Readiness}

Overall, we observed increases in eco-driving knowledge but not in any of the ecodriving behaviors. However, we found that there were certain individual and contextual factors 
that were important for eco-driving programs to be effective. These factors should be considered in future studies and are consistent with research into other types of organizational interventions (Neal \& Griffin, 2006).

Specifically, we found that eco-driving behaviors increased under conditions of either 1) high motivation, 2) high supervisor support for eco-driving, or 3) both high motivation and supervisor support (see Figure 1). Put differently, there was little behavior change when motivation and supervisor support were lacking. This speaks to the need for organizations to be supportive of newly learned skills and knowledge and to ensure employees have the right tools and resources to use their knowledge and skills (Salas, Tannenbaum, Kraiger \& SmithJentsch, 2012). In short, we found that the EcoDrive Program did increase eco-driving behaviors, but only when participants were motivated, perceived support from supervisors, or both.

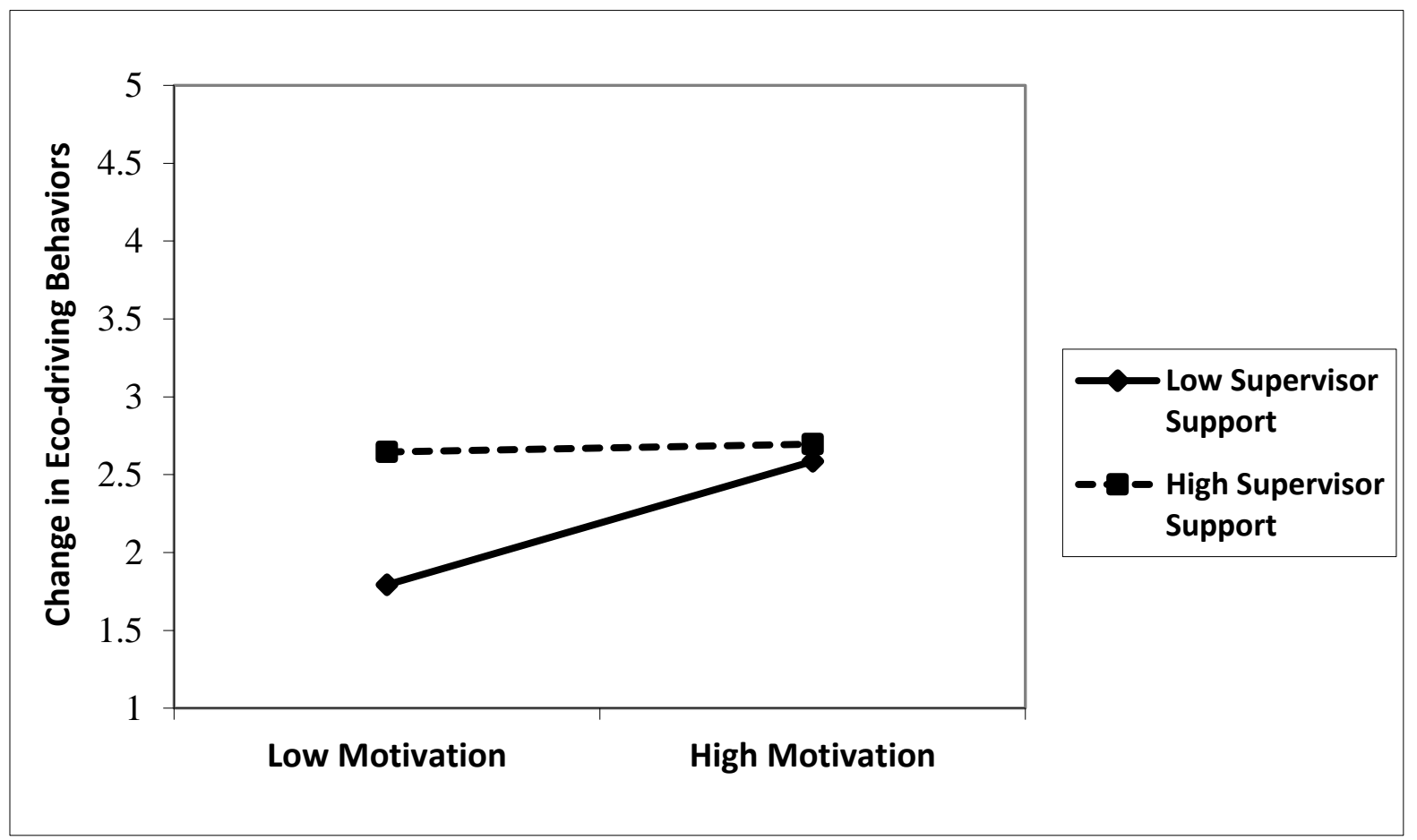

Figure 1. Interaction between motivation and supervisor support on change of eco-driving behaviors from Time 1 to Time 2 


\section{Suggestions for Future Research and Application}

Based on our evaluation of the EcoDrive Program and our analysis of the data we collected in the three organizations, we see several directions for future eco-driving programs and research.

1. Ensure driver motivation and organizational support prior to implementation. Our findings showed that simply distributing eco-driving materials in an organization may be enough to increase knowledge, but not enough to observe actual changes in behaviors. It is necessary for organizational leaders to actively support the EcoDrive Program, for supervisors to support the program, and for employees to be motivated to change their eco-driving behaviors. Moreover, participants who were motivated and perceived support from their supervisors did show improvement in eco-driving behaviors. Therefore, we recommend that future implementations of this program take the steps and time necessary to ensure that employees understand the program and are motivated to participate, and that supervisors communicate the importance of the program to employees.

2. Incorporate eco-driving into formal organizational policies, training, and programs. Rather than just a passive distribution of materials, we recommend that, as suggested by our organizational partners, the program be incorporated into organizational training and safety programs and be required of employees. Organizations should take the necessary steps to ensure, to as much extent as possible, that the organization and supervisory staff can provide support to employees who are being asked to change their driving behaviors. Furthermore, organizational leaders should consider whether their organization is ready for a behaviorchange program (i.e., whether they are prepared to offer the support and provide motivation and incentives for their employees). Sufficient time should be given for implementation.

3. Incorporate rigorous research design elements. Future studies should be evaluated using rigorous research design to allow more precise conclusions to be made from the data. Due to the nature of this project, which was a pilot study on a very tight timeline with a limited budget, we are less able to draw strong conclusions that the EcoDrive Program was responsible for the changes we observed in our study. For instance, other factors could have influenced our outcome variables in ways we were not able to evaluate. Ideally, future studies should use more sophisticated research designs (e.g., the use of control groups and random assignment to different eco-driving conditions). Such design elements would allow researchers to determine whether the changes observed in a study can be attributed to the intervention. Ideally, an evaluation research program should track fuel usage before, during and post intervention for each participant. Additional design elements should include vehicle type and miles driven. 


\section{Summary}

We compared our Time 1 eco-driving data to our Time 2 and Time 3 results to determine whether we observe changes in 1) eco-driving behaviors and practices and 2) whether individual and organizational factors have influenced these potential changes. Our results indicated that eco-driving knowledge increased during the EcoDrive Program, but that most eco-driving behaviors did not change. Furthermore, eco-driving behaviors did change when motivation, support for eco-driving, or both were present. Based on these results, we believe future eco-driving programs should 1) take steps to ensure driver motivation and organizational support prior to implementation of any such program; 2) incorporate eco-driving into formal organizational policies, training, and programs; and 3) incorporate rigorous research design elements to make strong conclusions from any data collected on an eco-drive program. 


\section{References}

Alliger, G. M., Tannenbaum, S. I., Bennett, W., Traver, H., \& Shotland, A. (1997). A meta-analysis of the relations among training criteria. Personnel Psychology, 50, 341-358.

Barkenbus, J. N. (2010). Eco-driving: An overlooked climate change initiative. Energy Policy, 38, 762-769.

Hammer, L. B., Kossek, E. E., Yragui, N. L., Bodner, T. E., \& Hanson, G. C. (2009). Development and validation of a multidimensional measure of family supportive supervisor behaviors (FSSB). Journal of Management, 35, 837-856.

Harvey. J., Thorpe, N., \& Fairchild, R. (2013). Attitudes towards and perceptions of Eco-driving and the role of feedback systems, Ergonomics, 56, 507-521.

Martin, E. W., Chan, N. D., Shaheen, S. A. (2012). How public education on Eco-driving can reduce both fuel use and greenhouse emissions. Journal of the Transportation Research Board of the National Academies, 2287, 163-173.

Neal, A., \& Griffin, M.A. (2006). A study of the lagged relationships among safety climate, safety motivation, safety behavior and accidents at the individual and group levels. Journal of Applied Psychology, 91, 946-953.

Salas, E., Tannenbaum, S. I., Kraiger, K., \& Smith-Jentsch, K. A. (2012). The science of training and development in organizations: What matters in practice. Psychological Science in the Public Interest, 13, 74-101.

Stillwater, T., \& Kurani, K. S. (2013). Drivers discuss ecodriving feedback: Goal setting, framing, and anchoring motivate new behaviors. Transportation Research Part F: Traffic Psychology \& Behaviour, 19, 85-96.

van der Voort, M., Dougherty, M. S., \& van Maarseveen, M. (2001). A prototype fuel-efficiency support tool. Transportation Research Part C: Emerging Technologies, 9(4), 279-296.

Van Eerde, W., \& Thierry, H. (1996). Vroom's expectancy models and work-related criteria: A meta-analysis. Journal of Applied Psychology, 81, 575-586.

Wogalter, M. S., \& Laughery, K. R. (1996). Warning! Sign and label effectiveness. Current Directions in Psychological Science, 5(2), 33-37.

Zaniboni, S., Fraccaroli, F., Truxillo, D.M., Bertolino, M., Bauer, T.N. (2011). Training valence, instrumentality, and expectancy scale (T-VIES-it). Factor structure and nomological network in an Italian sample. Journal of Workplace Learning, 23, 133-151. 
Zohar, D. (1980). Safety climate in industrial organizations: Theoretical and applied implications. Journal of Applied Psychology, 65, 96-102. 


\section{Appendix A}

Overview of the EcoDrive Educational Materials

\section{Top Ten Eco-driving Tips}

1. Drive at a steady and slower speed

2. Avoid quick starts and stops

3. Reduce the time your engine idles

4. Keep your tires inflated

5. Maintain your vehicle
6. Remove unnecessary weight from vehicle

7. Use heating and air conditioning sparingly

8. Close windows at high speeds

9. Choose the right oil

10. Plan ahead to consolidate trips

\section{Eco-driving Project Logo}

- A logo to include the top ten Eco-driving tips (see first page of this report)

\section{Eco-driving Educational Video(s)}

- A series of video shorts (15 to 45 seconds) developed to cover all of the Top Ten Ecodriving Tips

\section{Eco-driving Tip Card for Cars and Light Vehicle fleets}

- A rear view mirror hanging Eco-driving Tip Card.

\section{Eco-driving Prompt Static Clings for Light Vehicles}

- Prompt Static Clings that can be affixed to the inside of a vehicle windshield. The purpose of the Prompt Static Clings is to remind drivers to utilize the Top Ten Ecodriving Tips.

\section{Eco-driving Poster}

- A full color poster featuring the Top Ten Eco-driving Tips and how drivers can save money at the gas pump.

Web Site (including videos): http://www.oregon.gov/ODOT/TD/TP/pages/ecodrive.aspx 


\section{Appendix B}

Semi-structured Intake Interview Questions

1. Can you tell me how the fleets are currently being used?

a. Can you give me a couple of examples of how employees use the vehicles?

i. Is it mostly city driving or long distance?

b. How many employees are allowed to use the fleet vehicles?

c. Are any employees assigned to any specific vehicles? How many?

d. Who manages fleet use?

2. What type of training or orientation do employees go through before being able to drive a fleet vehicle?

a. Do these organizational practices change by department?

b. Who monitors driving use within each department?

3. What is the composition of the fleet (vans, cars)?

a. We would like to get a list of the type of vehicles you have in your fleet (type, make, model, year, mpg). We would also like to get any fuel reports that you may keep for your fleet.

i. How can we obtain this information?

b. Are there any hybrid or electric cars in the fleet now?

4. Do you think fuel use is an important issue for your organization?

a. Why do you (or do not) think this is an important issue?

b. How as the organization traditional dealt with fuel economy?

5. Do you think environmental issues are important to your organization?

a. Why do you think (or do not) think this is an important issue?

b. Do you think driving efficiently can affect environmental concerns?

6. What are the reasons you see as getting in the way of saving fuel in the fleets?

7. Have you heard of Eco-driving before this program?

8. Do you think Eco-driving is an effective way to save fuel?

a. Please elaborate on why or why not.

9. Can you tell me why you think the Eco-driving program may or may not work for your organization?

a. What do you think the reactions will be of the other employees in your organization toward the Eco-driving program?

b. Do you think other agencies will find this program effective? Why or why not? 
10. Does your organization promote any activities as ways to drive efficiently?

a. For example, are there any policies in place focused at driving habits such as accelerating or braking gradually or driving at a slow and steady speed?

b. Is maintenance of the fleets recommended as ways to save fuel or reduce $\mathrm{Co} 2$ emissions?

c. Do you discuss idling or trip planning with those who drive the fleets?

11. Do you have any concerns about the Eco-driving program?

12. Besides this Eco-driving program are there different ways you think may help to save fuel?

13. Employees will be contacted via email to alert them to PSU's involvement with the Ecodriving program. We are trying to decide who would be the best person to send this email.

a. Who do you think should send this email? Why?

b. How do you think this email should be sent out to reach those employees who drive the most? 


\begin{abstract}
Appendix C
Survey Questions

All questions appeared on each survey for all organizations, unless noted.
\end{abstract}

Proactive Personality (Time 1 only; Hillsboro/Washington only)

Response Scale: Strongly Disagree (1) to Strongly Agree (7)

1. I am constantly on the lookout for new ways to improve my life.

2. Wherever I have been, I have been a powerful force for constructive change.

3. If I see something I don't like, I fix it.

4. No matter what the odds, if I believe in something, I will make it happen

5. I excel at identifying opportunities.

6. I am always looking for better ways to do things.

Conscientiousness (Time 1 only; Hillsboro/Washington only)

Response Scale: Strongly Disagree (1) to Strongly Agree (7)

1. I am always prepared at work.

2. I pay attention to details at work.

3. I get tasks done right away at work.

4. I carry out my plans at work.

5. I make plans and stick to them at work.

Work self-efficacy (Time 1 only; Hillsboro/Washington only)

Response Scale: Strongly Disagree (1) to Strongly Agree (7)

1. I can successfully overcome obstacles at work.

2. I can effectively handle difficult tasks at work.

3. I have no problem meeting the expectations that my employer has for me.

4. I can successfully organize and prioritize my duties at work.

5. When at work, I am able to give full attention to my assignments.

6. I am confident in my ability to meet most deadlines on my job.

7. I am able to solve most work problems in a timely fashion.

8. I am more capable at doing my job than most other employees.

\title{
Energy-reducing attitudes
}

Response Scale: Strongly Disagree (1) to Strongly Agree (7)

1. I try to reduce energy consumption in general.

2. I am motivated to save energy.

3. I switch off lights whenever not in use.

4. I like to check my own car's miles per gallon ( $\mathrm{mpg}$ ).

5. Wasting energy annoys me. 


\section{EcoDrive Motivation (Time 1 only)}

Response Scale: Strongly Disagree (1) to Strongly Agree (7)

1. I want to learn about reducing fuel consumption.

2. I feel I want to know how to drive more efficiently.

3. I think it's important to learn how to save gasoline.

4. I am open to learning new skills that will improve my performance as a driver.

5. There are things that I can do that will influence fuel efficiency.

6. I can actually improve my car's fuel efficiency if I try.

7. If I put in the effort, I am able to engage in fuel saving behaviors at work.

8. If I try, I am able to follow fuel saving procedures.

Role Overload (Time 1 only; Hillsboro/Washington only)

Response Scale: Strongly Disagree (1) to Strongly Agree (7)

1. The amount of work I am expected to do is too great.

2. I never seem to have enough time to get everything done.

3. It often feels as if I have too much work for one person to do.

Workload (Time 1 only; Hillsboro/Washington only)

Response Scale: Strongly Disagree (1) to Strongly Agree (7)

1. My job requires me to work very fast.

2. My job requires me to work very hard.

3. My job leaves me with little time to get things done.

\section{Eco-driving Practices}

1. Overall, how well do you think that your fleet car is maintained? [Not well at all (1) to Very well (7)]

2. In terms of fuel usage, how efficiently do you think you drive your work vehicle now? [Very inefficiently (1) to Very inefficiently (7)]

3. When driving your primary work vehicle, how often do you adjust your driving behavior in ways to improve your fuel economy? [Never (1) to Always (7)]

4. When driving your primary work vehicle how often do you conduct a pre-trip inspection (e.g., check the oil and tire pressure)? [Never (1) to Always (7)]

5. On cold mornings, how long do you typically warm up the car before starting your trip? [0 seconds, About 15 seconds, About 30 seconds, About 45 seconds, About 1 minute, About 1.5 minutes, About 2 minutes, More than 2 minutes]

\section{Eco-driving Behaviors}

Response Scale: Very Unlikely (1) to Very Likely (7)

1. Drive at a slow and steady speed

2. Accelerate/break gradually 
3. Spend less time idling your engine

4. Keep tires inflated

5. Maintain your vehicle properly

6. Leave unnecessary weight out of your vehicle

7. Use the heating and cooling systems sparingly

8. Close windows at high speeds

9. Choose the correct oil for your vehicle

10. Plan ahead to consolidate trips

11. Avoid quick starts and stops

12. Conduct 'visual inspection' before each trip (Hillsboro only)

13. Conduct monthly vehicle maintenance inspection (Hillsboro only)

Typical Driving Practices (Time 1 only)

1. When you drive on the highway in free-flow traffic what cruising speed do you typically try to maintain? [Less than 45 miles per hour, 45 miles per hour, 50 miles per hour, 55 miles per hour, 60 miles per hour, 65 miles per hour, 70 miles per hour, 75 miles per hour, 80 miles per hour, 85 miles per hour, More than 85 miles per hour]

2. About how many hours do you expect to drive each week for work? [Fill-in]

3. Where do you typically drive for work? [City driving in traffic, City driving, no traffic, Long-distance driving (e.g., highway miles), Mix of both city and longdistance/highway miles]

4. What best describes the type of fleet vehicle you typically drive? [Light-duty (cars, sedans, light trucks), Heavy (transport vehicle, construction equipment, Neither/other (please write vehicle description below)]

5. About what percentage of the time that you spend driving for work are you pulling a trailer? [0\% to 100\%] (Hillsboro only)

\section{Organizational Support}

Response Scale: Strongly Disagree (1) to Strongly Agree (7)

1. My organization places a strong emphasis on efficient driving behaviors.

2. Eco-driving practices are given a high priority by my organization.

3. My organization considers eco-driving behaviors to be important.

\section{Supervisor Support}

Response Scale: Strongly Disagree (1) to Strongly Agree (7)

1. My supervisor places a strong emphasis on efficient driving behaviors.

2. The eco-driving program is given a high priority by my supervisor.

3. My supervisor considers eco-driving behaviors to be important. 


\section{Eco-driving knowledge}

1. I am aware of what "eco-driving" practices are and could briefly explain them to another person. [Response Scale: Strongly Disagree (1) to Strongly Agree (7)]

2. If you are able to, please provide one or two examples of what you think eco-driving consists of. If you can not think of an example, please mark an X in the box. [Coded as (1) if participant correctly named eco-driving behaviors and (2) if they could not]

Evaluate Intervention Materials (Time 2 and Time 3 only)

Response Scale: Yes (1) or No (2)

1. Have you seen the eco-driving tip card in your workplace or work vehicle?

2. Do you think the tip card was useful in increasing your knowledge about ecodriving?

3. Do you think the tip card was useful in increasing other people's knowledge about eco-driving?

4. How effective was the tip card about eco-driving in changing your driving behavior?

5. How effective do you think the tip card about eco-driving was in changing other people's driving behaviors?

6. Have you seen the eco-driving poster in your workplace?

7. Do you think the poster was useful in increasing your knowledge about eco-driving?

8. Do you think the poster was useful in increasing other people's knowledge about eco-driving?

9. How effective was the poster about eco-driving in changing your driving behavior?

10. How effective do you think the poster about eco-driving was in changing other people's driving behaviors?

11. Have you seen the eco-driving static cling in your workplace or work vehicle?

12. Do you think the static cling was useful in increasing your knowledge about ecodriving?

13. Do you think the static cling was useful in increasing other people's knowledge about eco-driving?

14. How effective was the static cling about eco-driving in changing your driving behavior?

15. How effective do you think the static cling about eco-driving was in changing other people's driving behaviors?

16. Have you visited the eco-drive website (http://www.oregon.gov/ODOT/TD/TP/Pages/ecodrive.aspx)?

17. Do you think the website was useful in increasing your knowledge about ecodriving?

18. Do you think the website was useful in increasing other people's knowledge about eco-driving?

19. Have you viewed the videos demonstrating eco-driving practices? 
Video Questions (Time 2 and Time 3 only)

Did you watch this video?

Response Scale: [Yes (1), No (2), Not sure (3)]

1. Compilation (all videos - about six minutes in length)

2. EcoDrive - General Tips

3. EcoDrive - Maintain Vehicle

4. EcoDrive - Tire Care

5. EcoDrive - Avoid idling

6. EcoDrive - Slow \& Steady

7. EcoDrive - Reduce Drag

How useful was this video to you?

Response Scale: [Not very useful (1) to Very useful (5)]

1. Compilation (all videos - about six minutes in length)

2. EcoDrive - General Tips

3. EcoDrive - Maintain Vehicle

4. EcoDrive - Tire Care

5. EcoDrive - Avoid idling

6. EcoDrive - Slow \& Steady

7. EcoDrive - Reduce Drag

Utility reactions (Time 2 and Time 3 only)

1. How useful do you think the eco-driving program is in helping to save fuel? [Not at all useful (1) to Very useful (7)]

2. How effective do you think the eco-driving program is overall? [Not at all effective (1) to Very effective (7)]

3. Do you think the eco-driving program has allowed you to learn new skills that you can use on your job? [Not at all (1) to Very much so (7)]

4. I learned something about driving efficiently that I can apply to my every-day driving (driving off-work time). [Strongly disagree (1) to strongly agree (7)]

\section{Open-ended questions (Time 2 and Time 3 only)}

1. Have you seen any other eco-drive materials in your workplace? If so, please tell us what they are and what you thought of them below.

2. Please tell us anything else about your reactions to the eco-drive materials that have been distributed in your workplace.

Demographics (Time 1 only)

1. Age 
2. Gender

3. Education

4. Ethnicity

5. Hours worked per week

6. Tenure department

7. Tenure with the city/county

8. Average hours worked per week

9. Full-time or seasonal employee (Hillsboro only) 


\section{Appendix D}

\section{Survey of Scales at Each Time Point}

\begin{tabular}{|c|c|c|c|c|c|c|}
\hline Scale & \# items & Source & T1 & T2 & T3 & Organization \\
\hline $\begin{array}{l}\text { Proactive } \\
\text { Personality }\end{array}$ & 6 & $\begin{array}{l}\text { Seibert S.E, Crant J.M, Kraimer } \\
\text { M.L (1999). }\end{array}$ & $x$ & & & $\begin{array}{l}\text { Washington Co. and } \\
\text { Hillsboro Parks }\end{array}$ \\
\hline Conscientiousness & 5 & $\begin{array}{l}\text { Positively worded IPIP } \\
\text { (http://ipip.ori.org/) }\end{array}$ & $x$ & & & $\begin{array}{l}\text { Washington Co. and } \\
\text { Hillsboro Parks }\end{array}$ \\
\hline Work self-efficacy & 8 & $\begin{array}{l}\text { Chen, G., Goddard, T. G., \& } \\
\text { Casper, W. J. (2004). }\end{array}$ & $x$ & & & $\begin{array}{c}\text { Washington Co. and } \\
\text { Hillsboro Parks }\end{array}$ \\
\hline $\begin{array}{l}\text { Energy-reducing } \\
\text { attitudes }\end{array}$ & 5 & $\begin{array}{l}\text { Harvey, J., Thorpe N., \& Fairchild, } \\
\text { R. (in press). }\end{array}$ & $x$ & $x$ & $x$ & All organizations \\
\hline $\begin{array}{l}\text { EcoDrive } \\
\text { Motivation }\end{array}$ & 5 & $\begin{array}{l}\text { Adapted from Zaniboni et al. } \\
\text { (2011) }\end{array}$ & $x$ & & & All organizations \\
\hline Role Overload & 3 & $\begin{array}{l}\text { Bolino, M.C. \& Turnley, W.H. } \\
\text { (2005) }\end{array}$ & $x$ & & & $\begin{array}{l}\text { Washington Co. and } \\
\text { Hillsboro Parks }\end{array}$ \\
\hline Workload & 5 & Spector \& Jex (1998) & $x$ & & & $\begin{array}{l}\text { Washington Co. and } \\
\text { Hillsboro Parks }\end{array}$ \\
\hline $\begin{array}{l}\text { Eco-driving } \\
\text { Practices }\end{array}$ & 5 & $\begin{array}{l}\text { Martin, E. W., Chan, N. D., } \\
\text { Shaheen, S. A. (2012). }\end{array}$ & $x$ & $x$ & $x$ & All organizations \\
\hline $\begin{array}{l}\text { Eco-driving } \\
\text { Behaviors }\end{array}$ & $11-13$ & $\begin{array}{l}\text { Martin, E. W., Chan, N. D., } \\
\text { Shaheen, S. A. (2012). }\end{array}$ & $x$ & $x$ & $x$ & All organizations \\
\hline $\begin{array}{l}\text { Typical Driving } \\
\text { Practices }\end{array}$ & $4-5$ & $\begin{array}{l}\text { Ex: How many hours do you } \\
\text { expect to drive each week for } \\
\text { work? Where do you typically } \\
\text { drive for work? }\end{array}$ & $x$ & & & All organizations \\
\hline $\begin{array}{l}\text { Organizational } \\
\text { Support }\end{array}$ & 3 & $\begin{array}{l}\text { Adapted from Neal \& Griffin } \\
(2006)\end{array}$ & $x$ & $x$ & $x$ & All organizations \\
\hline $\begin{array}{l}\text { Supervisor } \\
\text { Support }\end{array}$ & 3 & $\begin{array}{l}\text { Adapted from Neal \& Griffin } \\
\text { (2006) \& the PSS }\end{array}$ & $x$ & $x$ & $x$ & All organizations \\
\hline $\begin{array}{l}\text { Eco-driving } \\
\text { knowledge }\end{array}$ & 2 & & $x$ & $x$ & $x$ & All organizations \\
\hline $\begin{array}{l}\text { Evaluate } \\
\text { Intervention } \\
\text { Materials }\end{array}$ & 19 & & & $x$ & $x$ & All organizations \\
\hline Video Questions & 14 & & & $\mathbf{x}$ & $\mathbf{x}$ & All organizations \\
\hline Utility reactions & 3 & $\begin{array}{l}\text { Adapted from Kraiger et al. } \\
\text { (1993) }\end{array}$ & & $x$ & $x$ & All organizations \\
\hline $\begin{array}{l}\text { Open-ended } \\
\text { questions }\end{array}$ & 2 & & & $x$ & $x$ & All organizations \\
\hline Demographics & $8-9$ & & $\mathbf{x}$ & & & All organizations \\
\hline Total Items & $111-115$ & & 46-77 & $57-60$ & $57-60$ & \\
\hline
\end{tabular}


Appendix E

Table 11

Means Separated by Organization

Energy-reducing Attitudes (all participants, unmatched, by organization)

\begin{tabular}{|c|c|c|c|c|c|c|c|c|c|}
\hline Organization & \multicolumn{3}{|c|}{$\begin{array}{l}\text { Multnomah } \\
\text { County }\end{array}$} & \multicolumn{3}{|c|}{$\begin{array}{l}\text { Washington } \\
\text { County }\end{array}$} & \multicolumn{3}{|c|}{$\begin{array}{l}\text { Hillsboro Parks } \\
\text { Dept. }\end{array}$} \\
\hline Item & $\mathrm{T} 1$ & T2 & T3 & $\mathrm{T} 1$ & $\mathrm{~T} 2$ & T3 & $\mathrm{T} 1$ & $\mathrm{~T} 2$ & T3 \\
\hline $\begin{array}{l}\text { 1. I try to reduce energy } \\
\text { consumption in general. }\end{array}$ & 6.23 & 6.12 & 6.02 & 5.73 & 5.77 & 6.00 & 5.48 & 5.80 & 6.22 \\
\hline $\begin{array}{l}\text { 2. I am motivated to save } \\
\text { energy. }\end{array}$ & 6.20 & 6.04 & 6.09 & 5.80 & 5.62 & 5.86 & 5.30 & 5.50 & 6.11 \\
\hline $\begin{array}{l}\text { 3. I switch off lights } \\
\text { whenever not in use. }\end{array}$ & 6.46 & 6.30 & 6.19 & 6.07 & 6.00 & 6.14 & 5.96 & 6.10 & 6.33 \\
\hline $\begin{array}{l}\text { 4. I like to check my own } \\
\text { car's miles per gallon } \\
\text { (mpg). }\end{array}$ & 5.43 & 5.28 & 5.51 & 5.40 & 5.08 & 5.50 & 5.41 & 5.00 & 5.89 \\
\hline $\begin{array}{l}\text { 5. Wasting energy annoys } \\
\text { me. }\end{array}$ & 5.89 & 5.78 & 5.86 & 4.47 & 5.31 & 5.50 & 5.00 & 4.90 & 6.00 \\
\hline $\begin{array}{l}\text { Overall Energy-reducing } \\
\text { Attitudes Score }\end{array}$ & 6.03 & 5.90 & 5.93 & 5.70 & 5.55 & 5.80 & 5.42 & 5.46 & 6.11 \\
\hline
\end{tabular}

Note: Responses on 1 (Strongly disagree) to 7 (Strongly agree) scale. A response of 4 indicates neutral. 
The bar graph below visually highlights the differences between the energy reducing attitudes means across organizations and time points.

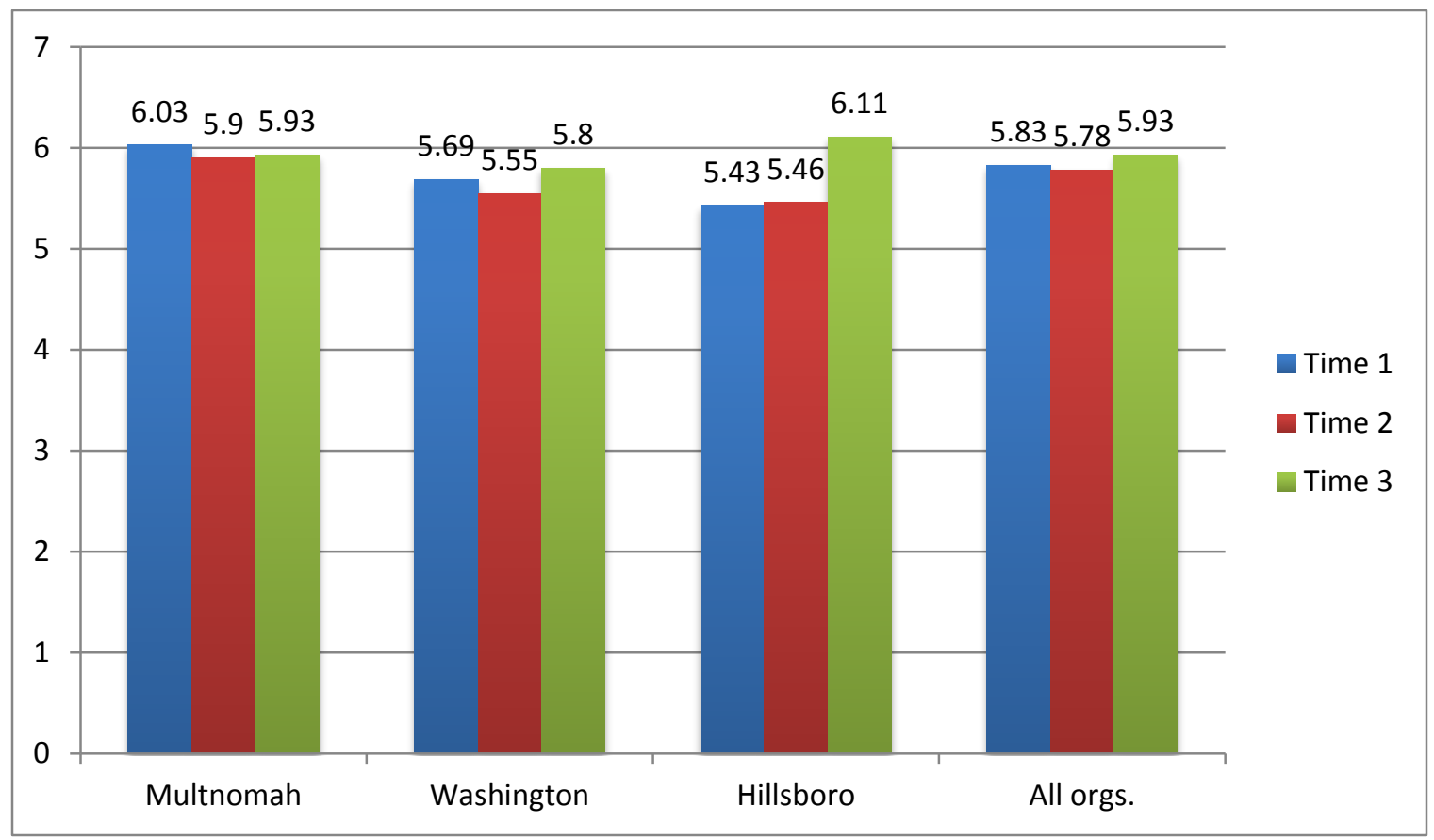

Figure 2. Energy reducing attitudes

Table 12

Eco-driving Practices (all participants, unmatched, by organization)

\begin{tabular}{|c|c|c|c|c|c|c|c|c|c|}
\hline \multicolumn{1}{|c|}{ Organization } & \multicolumn{3}{|c|}{ Multnomah County } & \multicolumn{3}{c|}{ Washington County } & \multicolumn{3}{l|}{ Hillsboro Parks Dept. } \\
\hline \multicolumn{1}{|c|}{ Item } & $\mathrm{T} 1$ & $\mathrm{~T} 2$ & $\mathrm{~T} 3$ & $\mathrm{~T} 1$ & $\mathrm{~T} 2$ & $\mathrm{~T} 3$ & $\mathrm{~T} 1$ & $\mathrm{~T} 2$ & $\mathrm{~T} 3$ \\
\hline $\begin{array}{l}\text { 1. Overall, how well do } \\
\text { you think that your fleet } \\
\text { car is maintained? }\end{array}$ & 5.25 & 5.36 & 5.33 & 5.29 & 5.50 & 5.55 & 5.20 & 5.60 & 5.56 \\
\hline $\begin{array}{l}\text { 2. In terms of fuel usage, } \\
\text { how efficiently do you } \\
\text { think you drive your work } \\
\text { vehicle now? }\end{array}$ & 5.34 & 5.56 & 5.44 & 4.85 & 6.09 & 5.46 & 5.35 & 5.20 & 5.11 \\
\hline $\begin{array}{l}\text { 3. When driving your } \\
\text { primary work vehicle, how } \\
\text { often do you adjust your } \\
\text { driving behavior in ways to } \\
\text { improve your fuel } \\
\text { economy? }\end{array}$ & 4.70 & 5.04 & 5.24 & 4.14 & 5.30 & 4.67 & 4.64 & 5.30 & 5.14 \\
\hline
\end{tabular}




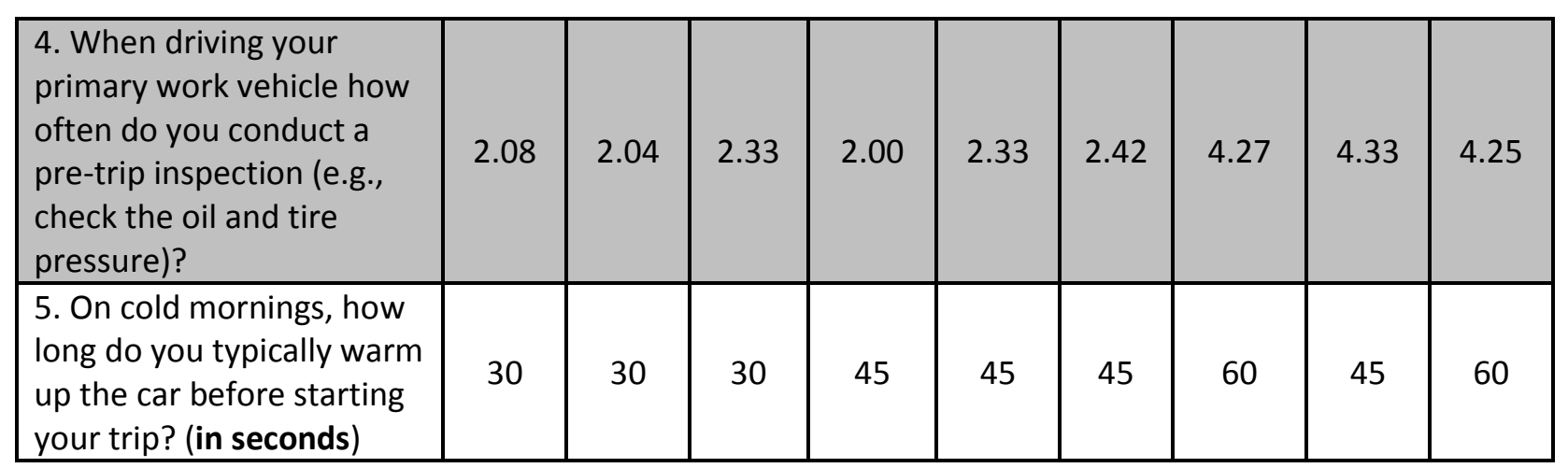

Note: Responses on 1 (Not well/never/inefficiently) to 7 (Very well/always/efficiently) scale. A response of 4 would be neutral.

Table 13

Eco-driving Behaviors (all participants, unmatched, by organization)

\begin{tabular}{|c|c|c|c|c|c|c|c|c|c|}
\hline Organization & \multicolumn{3}{|c|}{$\begin{array}{c}\text { Multnomah } \\
\text { County }\end{array}$} & \multicolumn{3}{|c|}{$\begin{array}{l}\text { Washington } \\
\text { County }\end{array}$} & \multicolumn{3}{|c|}{$\begin{array}{c}\text { Hillsboro Parks } \\
\text { Dept. }\end{array}$} \\
\hline Item & T1 & $\mathrm{T} 2$ & T3 & T1 & $\mathrm{T} 2$ & T3 & $\mathrm{T} 1$ & $\mathrm{~T} 2$ & T3 \\
\hline $\begin{array}{l}\text { 1. Drive at a slow and } \\
\text { steady speed. }\end{array}$ & 5.24 & 5.80 & 5.79 & 5.67 & 5.92 & 5.50 & 5.56 & 5.50 & 5.56 \\
\hline $\begin{array}{l}\text { 2. Accelerate/break } \\
\text { gradually }\end{array}$ & 5.46 & 5.92 & 5.81 & 6.00 & 5.77 & 5.00 & 5.78 & 5.60 & 5.33 \\
\hline $\begin{array}{l}\text { 3. Spend less time idling } \\
\text { your engine }\end{array}$ & 5.61 & 5.52 & 5.86 & 5.00 & 5.77 & 5.21 & 5.33 & 5.40 & 5.22 \\
\hline 4. Keep tires inflated & 4.54 & 4.02 & 4.04 & 4.80 & 5.23 & 4.43 & 5.85 & 5.50 & 5.44 \\
\hline $\begin{array}{l}\text { 5. Maintain your vehicle } \\
\text { properly }\end{array}$ & 4.76 & 4.46 & 4.62 & 5.07 & 5.31 & 4.93 & 5.67 & 5.70 & 5.89 \\
\hline $\begin{array}{l}\text { 6. Leave unnecessary } \\
\text { weight out of your vehicle }\end{array}$ & 5.34 & 5.24 & 5.02 & 5.60 & 5.46 & 4.57 & 4.89 & 4.90 & 5.67 \\
\hline $\begin{array}{l}\text { 7. Use the heating and } \\
\text { cooling systems sparingly }\end{array}$ & 4.89 & 4.46 & 4.93 & 4.00 & 4.54 & 4.14 & 4.04 & 3.80 & 5.00 \\
\hline $\begin{array}{l}\text { 8. Close windows at high } \\
\text { speeds }\end{array}$ & 6.15 & 6.12 & 5.98 & 5.60 & 5.31 & 4.86 & 4.74 & 5.00 & 5.78 \\
\hline $\begin{array}{l}\text { 9. Choose the correct oil } \\
\text { for your vehicle }\end{array}$ & 4.83 & 4.36 & 4.36 & 4.93 & 5.46 & 4.57 & 5.93 & 6.11 & 6.44 \\
\hline $\begin{array}{l}\text { 10. Plan ahead to } \\
\text { consolidate trips }\end{array}$ & 5.85 & 5.94 & 6.07 & 6.07 & 6.08 & 5.43 & 5.93 & 5.60 & 6.00 \\
\hline $\begin{array}{l}\text { 11. Avoid quick starts and } \\
\text { stops }\end{array}$ & 5.53 & 5.78 & 5.74 & 6.00 & 5.85 & 5.50 & 5.48 & 5.50 & 5.56 \\
\hline $\begin{array}{l}\text { Overall Eco-driving } \\
\text { Behavior Score }\end{array}$ & 5.27 & 5.24 & 5.35 & 5.34 & 5.52 & 4.92 & 5.38 & 5.30 & 5.63 \\
\hline
\end{tabular}

Note: Responses on 1 (Very unlikely) to 7 (Very likely) scale. A response of 4 indicates undecided. 
The bar graph below visually highlights the difference between the eco-driving behaviors across organizations and time points.

\section{Average Eco-driving Behaviors (all participants, unmatched, by organization)}

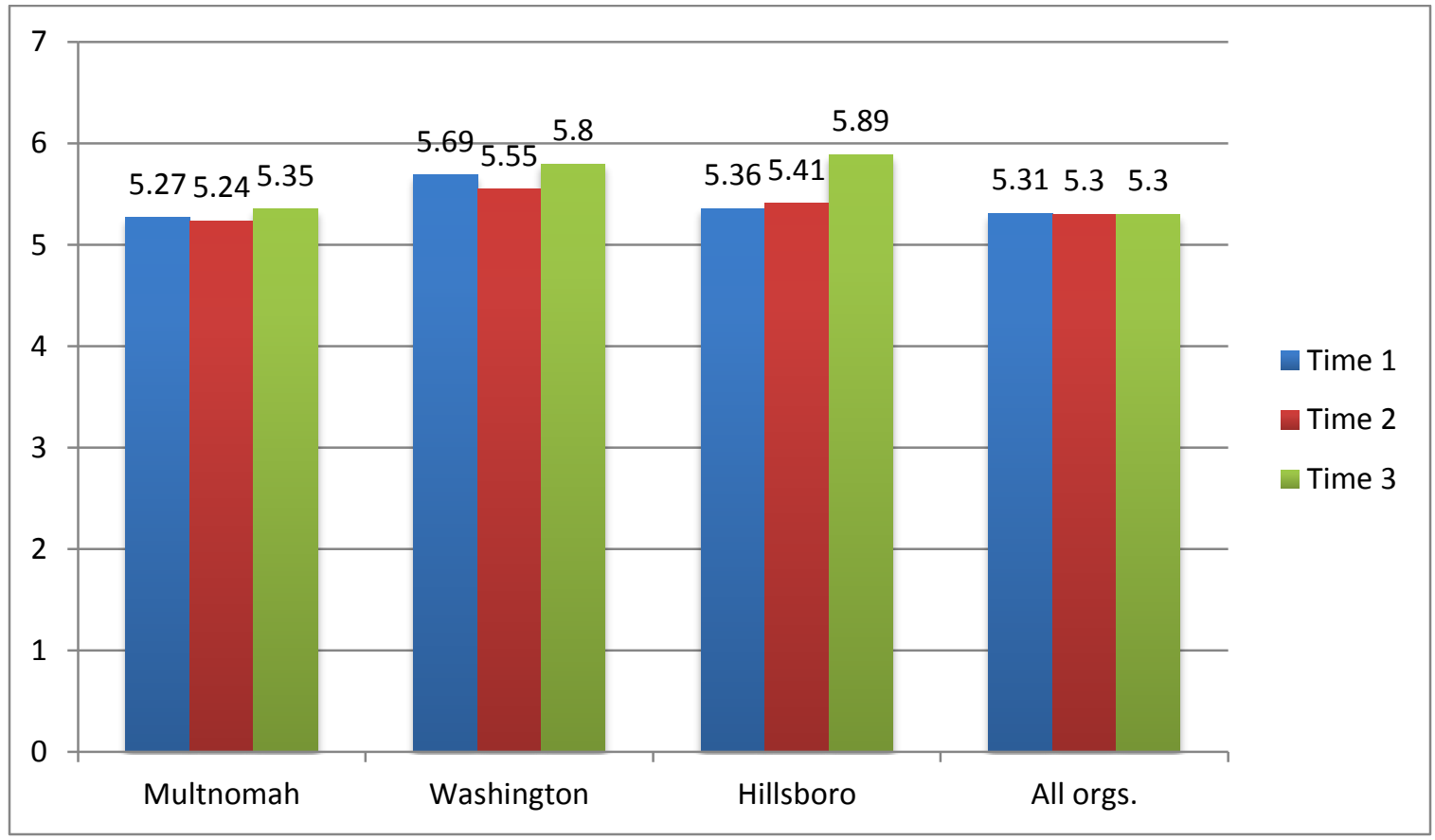

Figure 3. Eco-drive behavior

\section{Table 14}

Support for Eco-driving (all participants, unmatched, by organization)

\begin{tabular}{|c|c|c|c|c|c|c|c|c|c|}
\hline Organization & \multicolumn{3}{|c|}{$\begin{array}{c}\text { Multnomah } \\
\text { County }\end{array}$} & \multicolumn{3}{c|}{$\begin{array}{c}\text { Washington } \\
\text { County }\end{array}$} & \multicolumn{3}{c|}{$\begin{array}{c}\text { Hillsboro Parks } \\
\text { Dept. }\end{array}$} \\
\hline Item & T1 & T2 & T3 & T1 & T2 & T3 & T1 & T2 & T3 \\
\hline Organizational Support for Eco-driving & $\mathbf{4 . 4 0}$ & $\mathbf{4 . 4 2}$ & $\mathbf{4 . 4 9}$ & $\mathbf{4 . 4 7}$ & $\mathbf{4 . 9 0}$ & $\mathbf{4 . 8 2}$ & $\mathbf{5 . 3 6}$ & $\mathbf{5 . 4 1}$ & $\mathbf{5 . 8 9}$ \\
\hline Supervisor Support for Eco-driving & $\mathbf{3 . 7 5}$ & $\mathbf{3 . 8 0}$ & $\mathbf{3 . 6 4}$ & $\mathbf{4 . 4 0}$ & $\mathbf{4 . 8 5}$ & $\mathbf{5 . 0 3}$ & $\mathbf{5 . 0 0}$ & $\mathbf{5 . 2 2}$ & $\mathbf{5 . 7 0}$ \\
\hline
\end{tabular}

Note: Responses on 1 (Strongly disagree) to 7 (Strongly agree) scale. A response of 4 indicates neither disagree or agree. 


\section{Appendix $F$}

Evaluation of the Eco-driving Educational Materials

\section{Table 15}

Utility Evaluations (all participants, unmatched, by organization)

\begin{tabular}{|l|c|c|c|c|c|c|}
\hline \multicolumn{1}{|c|}{ Organization } & \multicolumn{2}{c|}{$\begin{array}{c}\text { Mult. } \\
\text { County }\end{array}$} & \multicolumn{2}{c|}{$\begin{array}{c}\text { Wash. } \\
\text { County }\end{array}$} & \multicolumn{2}{c|}{$\begin{array}{c}\text { Hillsboro } \\
\text { Parks } \\
\text { Dept. }\end{array}$} \\
\hline \multicolumn{1}{|c|}{ Item } & T2 & T3 & T2 & T3 & T2 & T3 \\
\hline $\begin{array}{l}\text { 1. How useful do you think the eco-driving program is in } \\
\text { helping to save fuel? }\end{array}$ & 4.90 & 4.67 & 4.70 & 4.40 & 4.38 & 5.00 \\
\hline $\begin{array}{l}\text { 2. How effective do you think the eco-driving program is } \\
\text { overall? }\end{array}$ & 4.49 & 4.37 & 4.44 & 4.10 & 4.38 & 5.29 \\
\hline $\begin{array}{l}\text { 3. Do you think the eco-driving program has allowed you } \\
\text { to learn new skills that you can use on your job? }\end{array}$ & 4.03 & 4.27 & 3.90 & 3.80 & 4.22 & 5.00 \\
\hline $\begin{array}{l}\text { 4. I learned something about driving efficiently that I can } \\
\text { apply to my every-day driving (driving off-work time). }\end{array}$ & 4.49 & 4.68 & 5.00 & 5.15 & 5.11 & 5.33 \\
\hline
\end{tabular}

Note: Responses on 1 (Not at all useful/ineffective/not at all/strongly disagree) to 7 (Very useful/very effective/very much so/strongly agree) scale. A response of 4 would be neutral.

\section{Table 16}

Percentage of the participants who reported viewing each of the educational materials

\begin{tabular}{|l|c|c|}
\hline \multicolumn{1}{|c|}{ Educational Material } & \multicolumn{2}{|c|}{ Frequency } \\
\hline & Time 2 & Time 3 \\
\hline Tip Card & $\mathbf{2 1 . 4 \%}$ & $\mathbf{2 3 . 6 \%}$ \\
\hline Window Cling & $\mathbf{1 1 . 4 \%}$ & $\mathbf{1 7 . 1 \%}$ \\
\hline Poster & $\mathbf{1 5 . 7 \%}$ & $\mathbf{1 8 . 6 \%}$ \\
\hline ODOT website & $14.3 \%$ & $\mathbf{1 7 . 9 \%}$ \\
\hline Videos & $\mathbf{1 1 . 4 \%}$ & $\mathbf{1 7 . 1 \%}$ \\
\hline
\end{tabular}

Note: Frequency is the percentage of the 140 participants who viewed the material.

\section{Table 17}

Percentage of participants who viewed each video and the perceived utility

\begin{tabular}{|l|c|c|c|c|}
\hline \multicolumn{1}{|c|}{ Video } & \multicolumn{2}{c|}{ Frequency } & \multicolumn{2}{c|}{ Mean Utility } \\
\hline & Time 2 & Time 3 & Time 2 & Time 3 \\
\hline $\begin{array}{l}\text { Have you viewed any of the videos } \\
\text { demonstrating eco-driving practices? }\end{array}$ & $\mathbf{1 1 . 4 \%}$ & $\mathbf{1 7 . 1 \%}$ & \\
\hline Which Video & $\mathbf{9 . 3 \%}$ & $\mathbf{1 4 . 3 \%}$ & $\mathbf{3 . 6 1}$ & $\mathbf{3 . 3 0}$ \\
\hline Compilation & &
\end{tabular}




\begin{tabular}{|l|c|c|c|c|}
\hline EcoDrive - General Tips & $\mathbf{6 . 4 \%}$ & $\mathbf{8 . 6 \%}$ & $\mathbf{3 . 6 2}$ & $\mathbf{3 . 1 4}$ \\
\hline EcoDrive - Maintain Vehicle & $\mathbf{5 . 0 \%}$ & $\mathbf{7 . 1 \%}$ & $\mathbf{3 . 6 7}$ & $\mathbf{3 . 0 7}$ \\
\hline EcoDrive - Tire Care & $5.0 \%$ & $\mathbf{7 . 1 \%}$ & 3.5 & 3.07 \\
\hline EcoDrive - Avoid idling & $\mathbf{5 . 7 \%}$ & $\mathbf{8 . 6 \%}$ & $\mathbf{3 . 4 2}$ & $\mathbf{3 . 2 7}$ \\
\hline EcoDrive - Slow \& Steady & $5.0 \%$ & $7.1 \%$ & $\mathbf{3 . 5}$ & $\mathbf{3 . 2}$ \\
\hline EcoDrive - Reduce Drag & $\mathbf{5 . 0 \%}$ & $\mathbf{6 . 4 \%}$ & $\mathbf{3 . 5}$ & $\mathbf{3 . 1 4}$ \\
\hline
\end{tabular}

Note: Mean utility is the average response on a 1 (Not effective) to 7 (Very effective) scale. A response of 4 would be neutral.

\section{Table 18}

\section{Perceived Utility of each of the Eco-driving Materials}

\begin{tabular}{|c|c|c|}
\hline \multirow[t]{2}{*}{ Tip Card } & \multicolumn{2}{|c|}{ Mean Utility } \\
\hline & Time 2 & Time 3 \\
\hline $\begin{array}{l}\text { Do you think the tip card was useful in increasing your } \\
\text { knowledge about eco-driving? }\end{array}$ & 4.64 & 4.57 \\
\hline $\begin{array}{l}\text { Do you think the tip card was useful in increasing other } \\
\text { people's knowledge about eco-driving? }\end{array}$ & 4.68 & 4.44 \\
\hline $\begin{array}{l}\text { How effective was the tip card about eco-driving in } \\
\text { changing your driving behavior? }\end{array}$ & 4.17 & 4.00 \\
\hline $\begin{array}{l}\text { How effective do you think the tip card about eco-driving } \\
\text { was in changing other people's driving behaviors? }\end{array}$ & 4.28 & 4.00 \\
\hline Window Cling & \multicolumn{2}{|c|}{ Mean Utility } \\
\hline $\begin{array}{l}\text { Do you think the window cling was useful in increasing } \\
\text { your knowledge about eco-driving? }\end{array}$ & 4.68 & 4.20 \\
\hline $\begin{array}{l}\text { Do you think the window cling was useful in } \\
\text { increasing other people's knowledge about eco-driving? }\end{array}$ & 4.78 & 4.00 \\
\hline $\begin{array}{l}\text { How effective was the window cling about eco-driving in } \\
\text { changing your driving behavior? }\end{array}$ & 4.68 & 4.25 \\
\hline $\begin{array}{l}\text { How effective do you think the window cling about eco- } \\
\text { driving was in changing other people's driving behaviors? }\end{array}$ & 4.76 & 3.94 \\
\hline Poster & \multicolumn{2}{|c|}{ Mean Utility } \\
\hline $\begin{array}{l}\text { Do you think the poster was useful in increasing your } \\
\text { knowledge about eco-driving? }\end{array}$ & 4.29 & 4.45 \\
\hline $\begin{array}{l}\text { Do you think the poster was useful in increasing other } \\
\text { people's knowledge about eco-driving? }\end{array}$ & 4.50 & 4.14 \\
\hline $\begin{array}{l}\text { How effective was the poster about eco-driving in } \\
\text { changing your driving behavior? }\end{array}$ & 4.22 & 4.10 \\
\hline $\begin{array}{l}\text { How effective do you think the poster about eco-driving } \\
\text { was in changing other people's driving behaviors? }\end{array}$ & 4.50 & 3.90 \\
\hline ODOT website & \multicolumn{2}{|c|}{ Mean Utility } \\
\hline $\begin{array}{l}\text { Do you think the ODOT website was useful in increasing } \\
\text { your knowledge about eco-driving? }\end{array}$ & 5.18 & 4.78 \\
\hline
\end{tabular}




\begin{tabular}{|l|c|c|}
\hline $\begin{array}{l}\text { Do you think the ODOT website was useful in } \\
\text { increasing other people's knowledge about eco-driving? }\end{array}$ & $\mathbf{5 . 5 0}$ & $\mathbf{4 . 6 0}$ \\
\hline $\begin{array}{l}\text { How effective was the ODOT website about eco-driving in } \\
\text { changing your driving behavior? }\end{array}$ & 4.53 & 4.52 \\
\hline $\begin{array}{l}\text { How effective do you think the ODOT website about eco- } \\
\text { driving was in changing other people's driving behaviors? }\end{array}$ & 4.93 & 4.47 \\
\hline
\end{tabular}

Note: Mean utility is the average response on a 1 (Not effective) to 7 (Very effective) scale. A response of 4 would be neutral. 
Appendix G

Exit Interview Questions for Fleet Managers/Organizational Contacts

The intent of this meeting is to learn about how the materials were distributed and promoted within Multnomah County. We also want to know of any informal feedback that you might have, or may have received from employees, about the program and the materials. This is important to understand as we make recommendations for future implementation.

1. In which departments were the materials distributed?

a. If you focused on specific departments, how did you decide on these departments?

b. Were there departments that you considered but thought they would not be a good fit for the program? If so, why?

c. Can you describe the participating departments?

i. Employee demographics that might be relevant to the program (Number of employees per department, \# that use vehicles, etc.)

ii. Types of jobs

iii. Driving patterns/usages in the department

iv. Are employees assigned a specific vehicle or is it random?

v. Supervisor involvement in the program

vi. Is there anything about these departments that you think made the program more or less effective?

2. In the departments where the materials were distributed, who handled the materials?

a. Was there a meeting upon delivery of the materials? That is, how was the transfer of the materials handled?

b. Who decided on placement of posters and tip cards?

c. Can you describe where the materials were placed?

d. Did the supervisors/managers make eco-driving a part of any staff updates or meetings?

e. Were the static clings placed in each car? 
f. Did employees watch the videos? (Or have you heard any feedback about them?)

i. If so, were employees given time at work to view the videos?

3. How were the materials promoted? That is, were any steps taken to increase awareness to the materials or to eco-driving?

4. Did other eco-driving practices already exist in the County or in these departments?

a. Such as idle free programs or trip consolidation mandates

5. Did you receive any informal feedback on the materials from supervisors or employees?

a. Overall, how did you think the materials were received by employees? That is, do you think that people liked or disliked the materials and the program?

b. Do you think the materials were effective in increasing knowledge about driving efficiently?

i. If so, why and if not, why not?

c. Did you observe or hear of employees sharing the eco-driving materials with each other?

6. How would you change the eco-driving materials if you could? By that we mean content of the materials or the media (posters, videos, etc.).

7. How well do you feel this program integrates into your organization's culture, management structure and goals?

8. Do you think other organizations would find these materials useful?

a. Why or why not?

9. Which types of organizations do you think these materials would be most beneficial?

10. What are the County's future plans with the materials (if any)?

a. Do you plan to distribute to other departments?

b. What challenges do you foresee in distributing the materials to other departments?

11. In thinking over the eco-drive project, is there something you would change in the way you distributed or promoted the materials? 
12. What (if any) barriers did you encounter in distributing the:

a. Surveys?

b. Materials?

13. Do you think that eco-driving will be promoted in your organization in the near future (next 5 years)?

a. Why or why not? 



\section{GOTREC \\ AND EDUCATION CONSORTIUM}

P.O. Box 751

Portland, OR 97207

OTREC is dedicated to stimulating and conducting collaborative multi-disciplinary research on multi-modal surface transportation issues, educating a diverse array of current practitioners and future leaders in the transportation field, and encouraging implementation of relevant research results. 